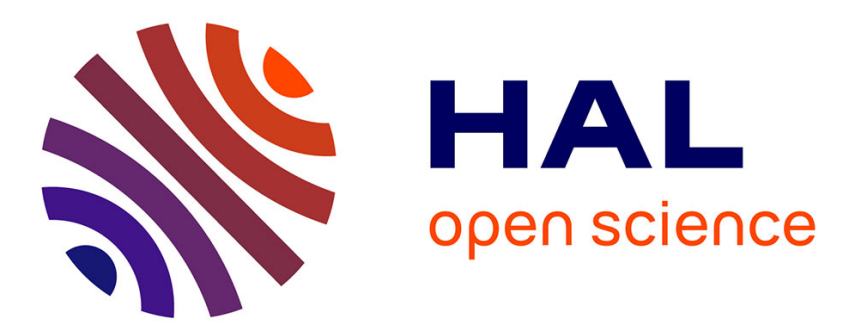

\title{
The manufacture of Aurignacian split-based points: an experimental challenge
}

Elise Tartar, Randall White

\section{To cite this version:}

Elise Tartar, Randall White. The manufacture of Aurignacian split-based points: an experimental challenge. Journal of Archaeological Science, 2013, 40 (6), pp.2723-2745. 10.1016/j.jas.2013.02.009 . hal-02355494

\section{HAL Id: hal-02355494 \\ https://hal-univ-tlse2.archives-ouvertes.fr/hal-02355494}

Submitted on 13 Nov 2019

HAL is a multi-disciplinary open access archive for the deposit and dissemination of scientific research documents, whether they are published or not. The documents may come from teaching and research institutions in France or abroad, or from public or private research centers.
L'archive ouverte pluridisciplinaire HAL, est destinée au dépôt et à la diffusion de documents scientifiques de niveau recherche, publiés ou non, émanant des établissements d'enseignement et de recherche français ou étrangers, des laboratoires publics ou privés. 


\title{
The manufacture of Aurignacian split-based points: an experimental challenge
}

\author{
Elise $\operatorname{Tartar}^{\mathrm{a}, *}$, Randall White ${ }^{\mathrm{b}}$ \\ ${ }^{a}$ UMR 7041, Equipe Ethnologie Préhistorique, Maison de l'Archéologie et de l'Ethnologie, 21 allée de l'Université, F-92023 Nanterre cedex, France \\ ${ }^{\mathrm{b}}$ Center for the Study of Human Origins (CSHO), Department of Anthropology and UMI 3199 CNRS - NYU, New York University, New York, NY 10003, USA
}

\section{A R T I C L E I N F O}

\section{Article history:}

Received 18 December 2012

Received in revised form

5 February 2013

Accepted 7 February 2013

\section{Keywords:}

Aurignacian

Hunting

Split based points

Tongued pieces

Antler technology

Abri Castanet

Abri Blanchard

\begin{abstract}
A B S T R A C T
Hunting is one of the areas of human activity that sees the most significant changes in the period from 40 000-35 000 BP in Europe. In this respect, the Aurignacian technocomplex shows technical innovations, notably with the fabrication of split-based points (SBP) in antler and the mass production of bladelets, arguably to serve as weapon armatures. Yet, little experiment work has been dedicated to this question. To begin to fill this gap, we have designed an experimental program devoted to testing and assessing the design, manufacture and use of Aurignacian weaponry.

In this paper, we present the very first stage of this project, focused on the fabrication of SBP's and particularly the question of the creation of the basal splits, an issue much-debated since the 1920's. From our replicative experiments and comparisons with the rich collections from Abris Castanet and Blanchard, we conclude that the incision, flexion and cleavage procedure (IFC) applied to SBP's combines the techniques proposed by previous authors. The use of the IFC procedure has been identified in at least 23 sites in SW Europe. Importantly, because this procedure is rigidly conditioned by the physical and mechanical properties of antler, it is unlikely that another technical solution was possible to create the basal splits.
\end{abstract}

(c) 2013 Elsevier Ltd. All rights reserved.

\section{Introduction}

Along with the development of personal ornamentation and the invention of figurative art, hunting is the area of human activity that sees the most significant changes in the period from 40 000-35 000 BP in Europe. In this respect, the Aurignacian technocomplex shows technical innovations, notably with the fabrication of split-based points (SBP) in antler (Didon, 1911a; Peyrony, 1928; Henri-Martin, 1931; Leroy-Prost, 1975, 1979; Knecht, 1991, 1993; Liolios, 1999) and the mass production of bladelets, arguably to serve as weapon armatures (Kuhn, 2002; Bon, 2002, 2005; Teyssandier, 2007, 2008; Bordes et al., 2008; Bon et al., 2010). Subsequently, bladelets and osseous points saw a strong expansion and lasted, in one form or another, throughout the entire Upper Paleolithic (Bon et al., 2010).

With the Aurignacian, new importance seems to be given to hunting with a specialization of related equipment. Indeed, since the Early Aurignacian, each osseous raw material (bone, antler, ivory) is mainly restricted to a particular technological domain (domestic; hunting; personal ornamentation and portable art) and

\footnotetext{
* Corresponding author. Tel.: +33 (0)6 22489533.

E-mail addresses: elise.tartar@gmail.com (E. Tartar), randall.white@nyu.edu (R. White).
}

antler becomes the raw material par excellence for the fabrication of spear points (Liolios, 1999; Tartar et al., 2006). Even bladelet production becomes autonomous and totally independent from blade debitage reserved for the manufacture of domestic equipment (Kuhn, 2002; Bon, 2002, 2005; Teyssandier, 2007, 2008; Bordes et al., 2008; Bon et al., 2010). This autonomy of different functional domaines represents a distinct departure from previous technical traditions (Mousterian, Chatelperronian) where osseous points are absent and where different lithic products are integrated into one and the same chaîne opératoire.

Some have proposed that these technological changes reflect social transformations: stronger individuality of hunting equipment in response to stronger individuation of hunters themselves (Bon, 2009). More heavy duty Mousterian weapons, such as wooden spears, and lances armed with lithic points (Oakley et al., 1977; Callow, 1986; Thieme, 1997; Shea, 1988, 2006; Boeda et al., 1999; Shea et al., 2001; Villa and Lenoir, 2006; Villa et al., 2009), used in collective hunts, gave way to lighter projectile weapons, notably throwing weapons armed with points equipped with lithic and osseous armatures (Kuhn, 2002; Lebrun-Ricalens, 2005; Bon et al., 2010; Knecht, 1997; Liolios, 2006). The killing power of these new weapon forms permitted, even favored, individual hunting practices (Bachellerie et al., 2011).

Evaluation of these ideas needs to take into account data on the nature of the sites themselves, their location on the landscape and 
their place within regionally organized "territories" (Bachellerie et al., op. cit.). However, a solid understanding of the ways weapons functioned is also fundamental, and can only be acquired through rigorous experimentation. While experimental research into Mousterian weaponry has expanded in recent years (Plisson and Beyries, 1998; Shea et al., 2001; Smith, 2003; Sisk and Shea, 2009), the same is not true of Aurignacian hunting equipment.

Use-traces on bladelets from a few Aurignacian assemblages have been taken to indicate their use as shearing armatures mounted laterally on projectile points (Hays and Lucas, 2001; Bon, 2002; O'Farrell, 2005; Pelegrin and O'Farrell, 2005). To this day, only Hays and Lucas's (2001) analysis of Dufour bladelets from level IX at Flageolet I (Dordogne, France) has made use of experimental reconstruction, and even that was exploratory and limited to late Aurignacian bladelets. For osseous materials, the experimental work of Knecht quickly became the primary reference concerning the conception and use of SBP's, presumed to have been used as projectile weapons (Knecht, 1991, 1993, 1997). Nonetheless, we will show below that there is now reason to doubt some of Knecht's conclusions. In order to test previous propositions and to place our own thinking on a secure footing, we established an experimental program aimed at understanding the design, fabrication and use of Aurignacian weapons (note 1 ). The first stage of this project focused on the design and fabrication of SBP's. Careful attention was paid to the question of the creation of the basal splits, an issue much debated since the 1920's. It is our position that understanding the use of weapons armed with PBF's requires a solid knowledge of techniques of fabrication and hafting of these osseous points.

Via experimental replication we attempted the two hypothesized procedures: that of Peyrony $(1928,1935,1946)$ involving transverse incision (note 2) and flexion and that of Henri-Martin (1931), adopted by Knecht (1991, 1993, 1997), which envisages a simple cleavage of the bases. We present here the results of these replicative experiments and comparisons with the rich collections of SBP's from two key French Early Aurignacian sites: Abri Castanet and Abri Blanchard.

\section{Historical background on the making of a basal split}

Emblematic of the Aurignacian, the pointe à base fendue or pointe d'Aurignac was identified very early in the history of Paleolithic archaeology (Lartet, 1861). It quickly served as an index fossil to date the archaeological assemblages in which it was present, long before the periodization of Peyrony in which it was presented (Peyrony, 1933) as a marker of the Early Aurignacian (Aurignacian I). Its wide geographic distribution, from Spain to the Near East, reinforced the idea of a homogenous Early Aurignacian phase that went hand in hand with an intensive and rapid dispersal of Modern Humans across Europe (Teyssandier and Liolios, 2008). This view of things has since been questioned in light of the recognition of an even older Aurignacian, the Proto- or Archaic Aurignacian (Laplace, 1966; Bazile and Sicard, 1999; Bon, 2002; Bon and Bodu, 2002; Bordes, 2002; Teyssandier, 2007), which has yielded the oldest examples of SBP's (Broglio et al., 1996; Ortega Cobos et al., 2005; Normand et al., 2007; Szmidt et al., 2010). In spite of these refinements, in Europe SBP's remain a hallmark of the early phases of the Aurignacian.

In his groundbreaking publication on Abri Blanchard, Didon was the first to undertake a detailed description of SBP's (Didon, 1911a). However, it was Peyrony who first examined the way in which the split-bases were created (Peyrony, 1928, 1935, 1946). He recognized a consistent association in the many Early Aurignacian levels that he had excavated (note 3 ) of flat antler pieces that showed transverse incisions on both faces delimiting a central languette or tongue. Whereas Didon had interpreted these pièces à languette or tongued pieces (TP) as fragments of broken daggers or spear points, not seeing any relationship to the fabrication of SBP, Peyrony saw a technical link between SBP's and the TP's (Peyrony, 1928): he saw the latter as the missing body of antler between the two "wings" of the split base (Fig. 1.1). He reasoned accordingly that TP's were waste products of the fabrication of SBP's. Peyrony imagined a procedure by which transverse incision and flexion of antler blanks were employed to create the split base (Fig. 1.1). According to his hypothesis, an antler blank was prepared, then incised transversely
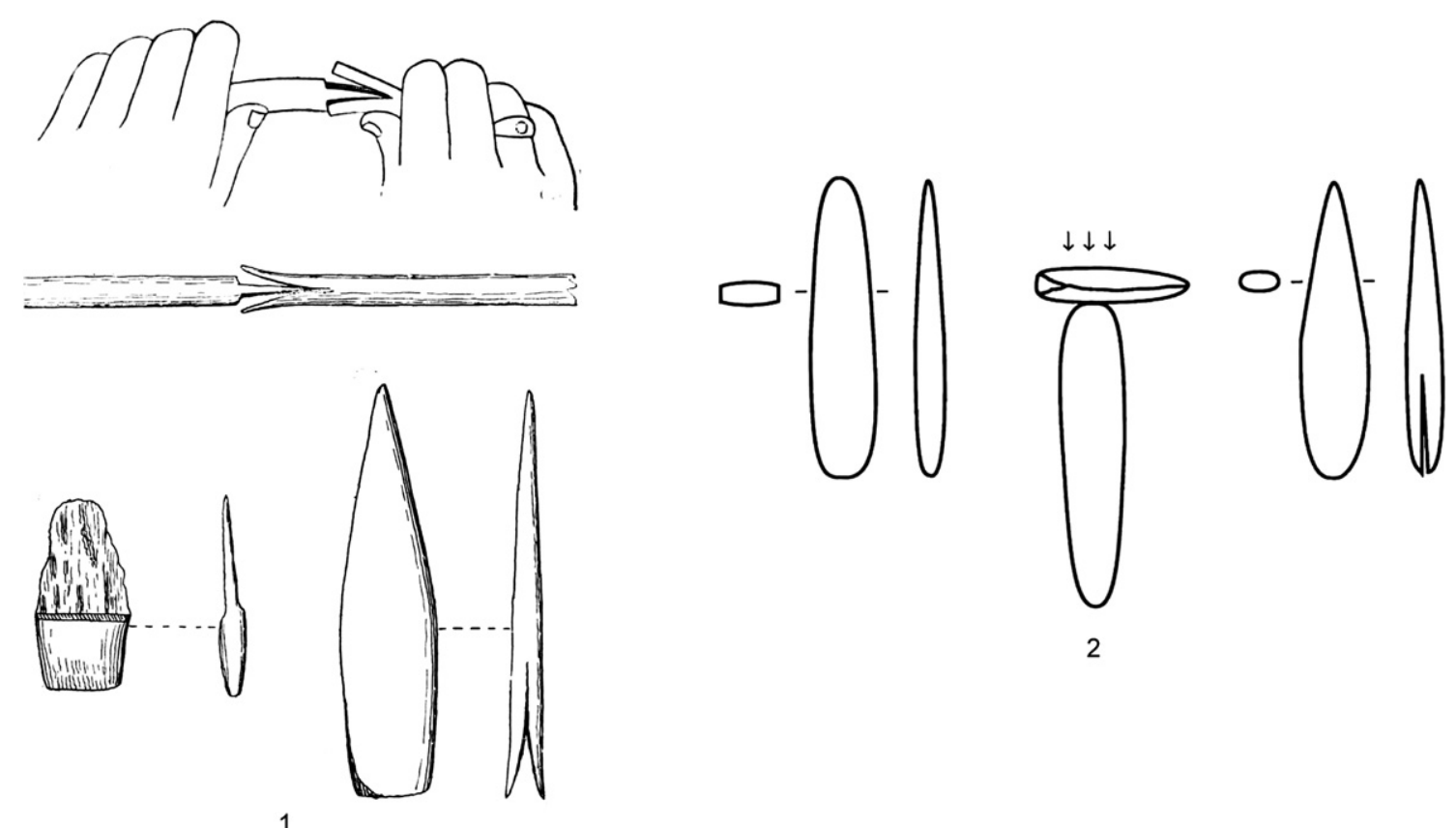

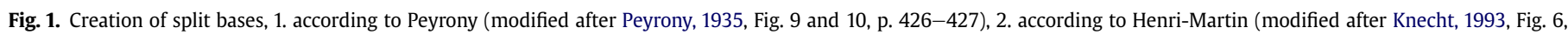
p. 150). 
on both faces to a depth of one quarter to a one third of the total thickness. Grasping the blank at each end, the bending of one face initiated a split departing from the bottom of the incision. Flexing in the opposite direction resulted in a similar split on the other face which resulted in the separation of the two masses of antler: one with a split extremity, the other with a tongue.

Henri-Martin disagreed, at least as far as the SBP's from La Quina (Charente) were concerned. At La Quina he had observed no missing material between the wings of the basal split. He proposed an alternative method (Henri-Martin, 1931), that of a split accomplished by cleavage, using a wedge applied to the proximal end of the blank by indirect percussion (Fig. 1.2).

In the years that followed, researchers studying Early Aurignacian osseous assemblages tended to side with Peyrony's hypothesis to explain the presence of TP's in association with SBP's (Delage, 1938; Vezian and Vezian, 1970; Bricker, 1995). However, given the absence of TP from certain assemblages, Henri-Martin's hypotheses remained in play (G. Henri-Martin, 1963) and some analysts considered the two approaches to have existed simultaneously (Leroy-Prost, 1975; Hahn, 1988). Newcomer's experimental success in producing SBP by both methods added credibility to the latter position (Newcomer, 1977).

In the 1990's, Knecht's work on the manufacture and hafting of SBP's (Knecht, 1991, 1993, 1997) from about 30 sites in France (including Abri Castanet and La Quina), Belgium and Germany raised new doubts about Peyrony's hypothesis and gave new life to Henri-Martin's cleavage hypothesis. In no site did Knecht observe an absence of material between the wings of the points, which led her to dismiss Peyrony's hypothesis. In turn, she resurrected the question of the status of the TP. If they weren't debris from SBP production, what were they? And why were they always associated with SBP?

After experimentation, she proposed that TP were related to hafting of SBP's. Having identified use traces on the inside surfaces of certain wings, she hypothesized that SBP's were fixed into shafts, the end of which was formed into a U-shape then bound with a ligature leaving open a small aperture for the insertion of a clavette or "shim" (note 4) between the wings of the point. In conformity with this hypothesis, she proposed that the TP resulted from the extraction of these triangularly-sectioned shims (Fig. 2.1). She found support for this hypothesis in the form of 27 shims from Abri Castanet which she interpreted as pieces extracted from each side of the tongue on TP's (Fig. 2.2).

Today, the Knecht hypothesis (basal cleavage of the points and production of shims from TP's) is widely accepted (Liolios, 1999, 2006; Cattelain, 2010; Tejero et al., 2012), but certain data lead us to be skeptical. How do we explain, for example, the total absence of antler shims in sites yielding both SBP's and TP's? Knecht's interpretation rests solely on the 27 pieces from Abri Castanet. Moreover, experimental tests by Nuzhnyi have confirmed the viability of transverse incision-and-flexion for which he proposes two distinct variants (Nuzhnyi, 1998). One of these yields rather atypical TP's (with a unifacial incision or no tongue) of which we have seen examples in archaeological assemblages. More recently, Pétillon has observed stigmata on the bases of SBP's from the Grotte des Hyènes at Brassempouy that provide further support for Peyrony's hypothesis (Pétillon, in press).

In studying archaeological assemblages, it is difficult to determine which of the two hypothesized procedures was applied prehistorically. Unfortunately, Knecht does not describe, or at least underdescribes, her experiments and she provides no drawings or photographs of her experimentally produced pieces. Nuzhnyi, on the other hand, described his experiments but made no observations or comparisons on archaeological materials. Consequently, we have sought to undertake both procedures in order to judge their
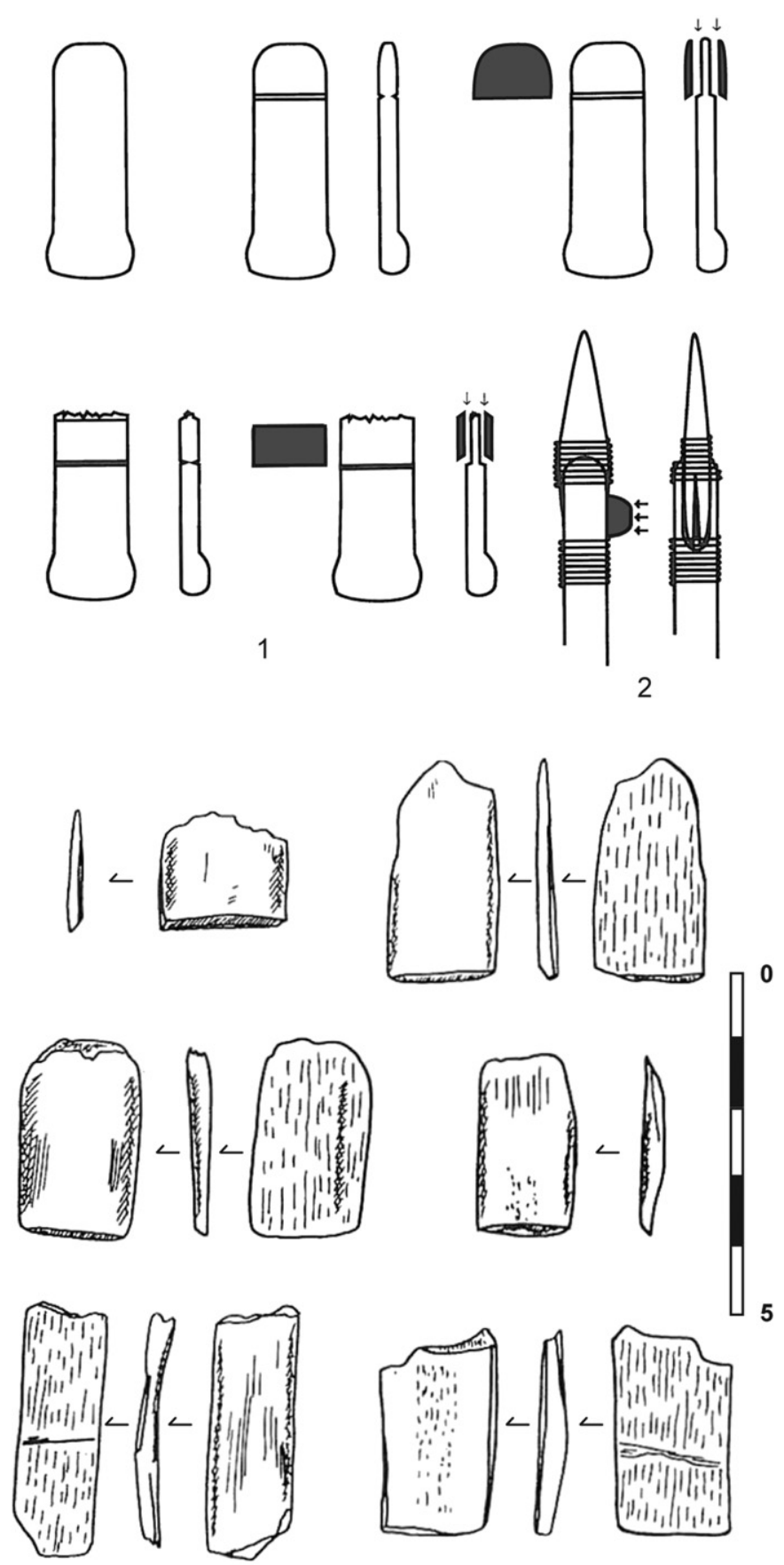

3

Fig. 2. Production and use of shims according to Knecht. 1. Operational chain for the production of shims from TP's. 2. Hypothetical use of shims. 3. Pieces interpreted as shims, Abri Castanet, north sector (drawings modified after Knecht, 1993, Fig. 7, 8 and 11, p. 152, 153 and 155).

viability and to create a reference sample to compare to the archaeological material from Abri Castanet and Abri Blanchard.

\section{Archaeological data}

\subsection{Castanet and Blanchard shelters}

Abris Castanet and Blanchard are part of a concentration of archaeological sites in the Vallon de Castel-Merle, a tributary valley 
of the Vézère River situated in the commune of Sergeac, Dordogne (Fig. 3). Situated on the east slope of this karstic dry valley, the two collapsed rock shelters, approximately $25 \mathrm{~m}$ apart, occupy a long bedrock terrace or platform about $12 \mathrm{~m}$ above the current valley bottom.

The Abri Blanchard was the first to be excavated. In 1882, local tobacco inspector Reverdit tested a small portion of the deposit constituted largely of roof collapse debris but, deterred by impenetrable blocks, he was unable to descend to the base of the sequence. The discovery of an ivory bead on the disturbed surface of the site in 1909 led Castanet, a local farmer and sometimes archaeological laborer, to excavate a trench and thereby convince amateur archaeologist and hotel owner Didon to lease the land and to undertake excavations. Between 1910 and 1912, Castanet was employed by Didon to excavate the site. Two archaeological levels were identified, the lowermost directly on the bedrock platform (B) separated from the uppermost (D) by a sterile layer (C). Both are attributed to Aurignacien I (Sonneville-Bordes, 1960) on the basis of
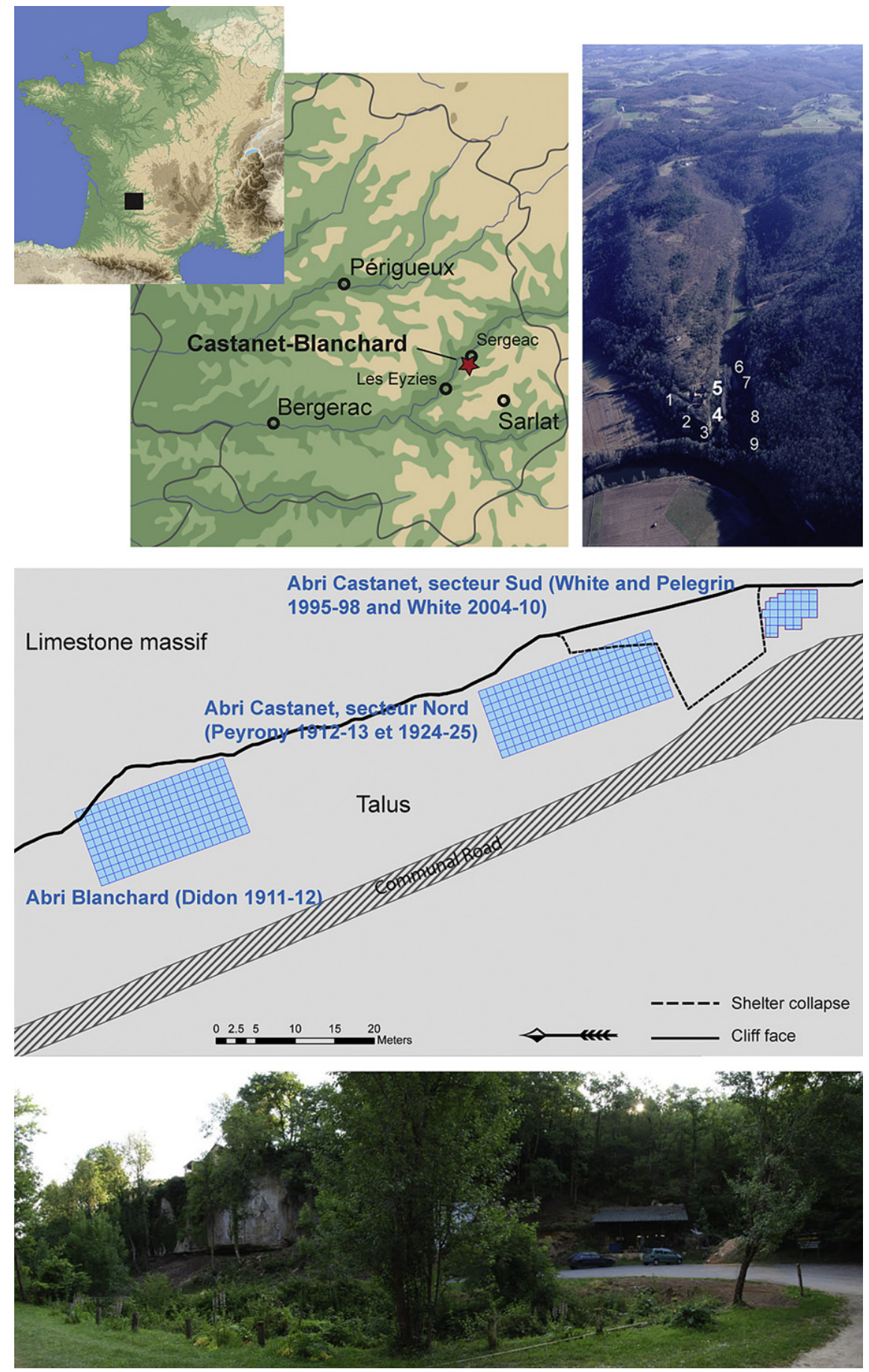

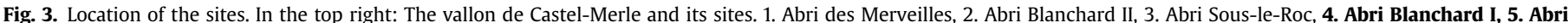

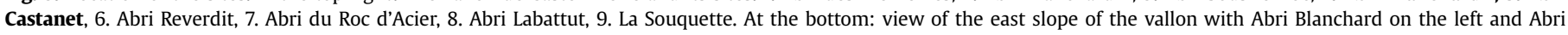
Castanet (south sector) on the right. 
the lithic industry and the presence of numerous SBP's (Didon, 1911a, 1911b).

Abri Castanet, $25 \mathrm{~m}$ to the south, was discovered by Castanet while he was still employed in the excavation of Abri Blanchard. He convinced Peyrony to lease the site and to employ him to excavate it, which he did in 1911-1912 and again briefly in 1924-1925. Like Didon at Abri Blanchard, Peyrony would distinguish two archaeological layers at Abri Castanet ( $A$ and $C$ ), the former directly on the bedrock platform, separated from the second by a sterile layer (B). However, Peyrony's chronological attribution of the two layers differed from that at Blanchard: he assigned the lowermost and very rich layer A to Aurignacian I on the basis of typical Aurignacian blades and numerous SBP and the uppermost and much poorer layer B to Aurignacian II on the basis of the discovery of two losenge-shaped points. Nonetheless, the stratigrahic sections published by each of these archaeologists are strikingly similar (Peyrony, 1935, Fig. 2, p. 419 and Didon, 1911a, Fig. 2, p. 250) and Castanet, like many researchers after him (Sonneville-Bordes, 1960; Delluc and Delluc, 1978), was convinced that Abris Castanet and Blanchard were two extremities of the same site.

In 1994, White and Pelegrin would re-test the stratigraphic profile left by Peyrony in the northern sector of Abri Castanet. After a series of successful soundings, they would then excavate the southern sector of the site from 1995 to 1998 . The excavation of this sector was continued down to bedrock under White's direction from 2005 through 2010 . These excavations revealed the equivalent of Peyrony's level A situated directly on bedrock and clearly attributable to the same Early Aurignacian. More than a dozen ${ }^{14} \mathrm{C}$ dates on faunal bone provide a mean date for the occupation of 32400 non cal. BP (White et al., 2012). In contrast, the overlying layer, attributed by Peyrony to Aurignacian II, is demonstrably intrusive and in secondary position. This deposit is linked to a phase of intensive water erosion during which sediments from the plateau above and the archaeological materials they contained were deposited above the collapsed ceiling of the shelter (Texier, 1994; Kervinio et al., 2006).

Then in 2009, the cleaning and superficial leveling of the talus in anticipation of an electrical resistivity survey, revealed in situ deposits remaining at Abri Blanchard. These were excavated in 2011 and 2012 and yielded in situ Early Aurignacian deposits, situated directly on bedrock.

\subsection{Archaeological material}

The Early Aurignacian levels at Castanet and Blanchard have yielded a rich assemblage of lithic and osseous materials, the latter consisting of both tools and weapon tips. As importantly, both sites show numerous waste products, evidence for intensive on-site fabrication of osseous objects. Personal ornaments in a diversity of materials (marine shell, mammal teeth, mammoth ivory, talc, bone and antler) are also abundant. Many of the raw materials employed are from sources $200-600 \mathrm{~km}$ distant, attesting to long

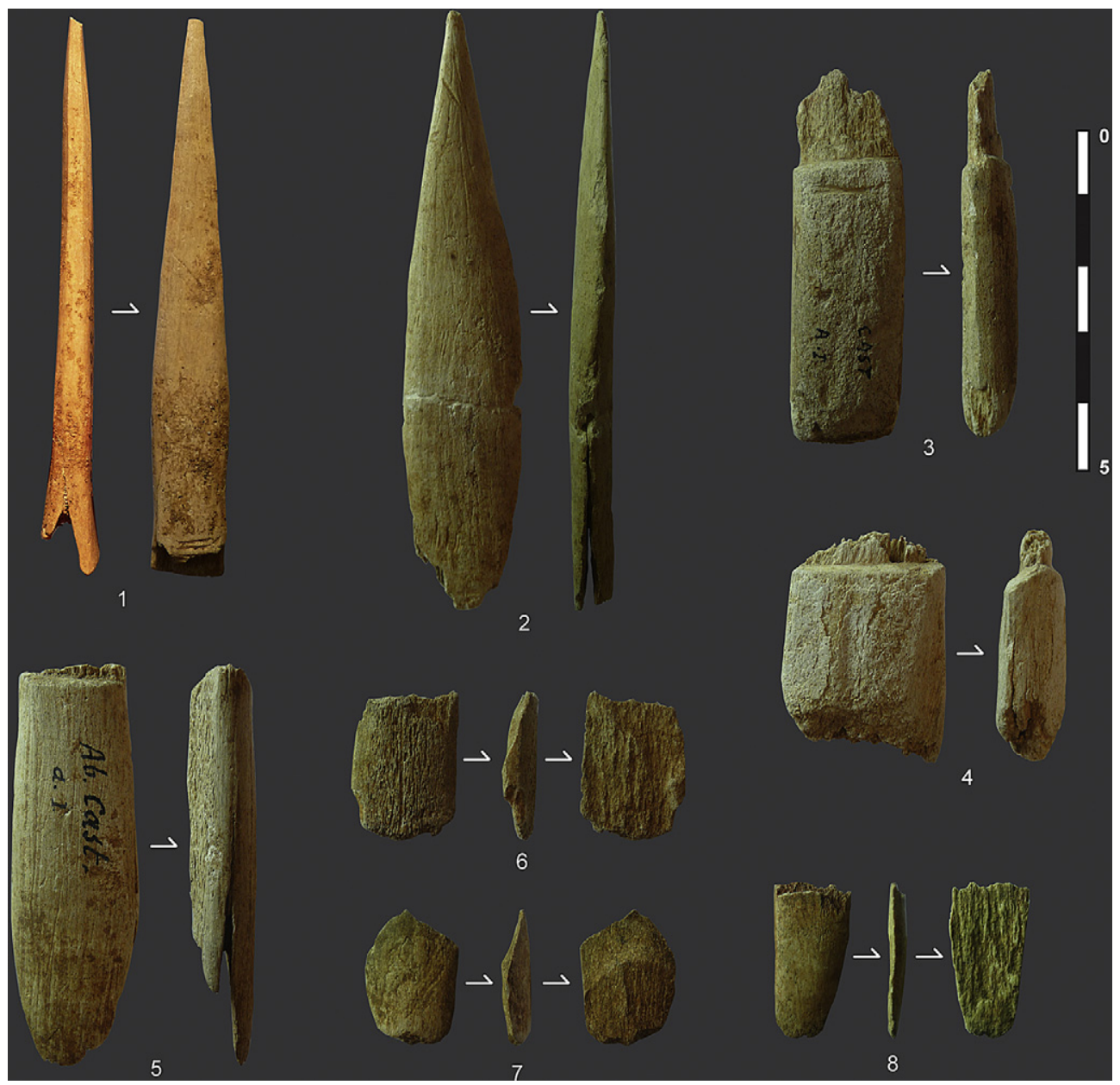

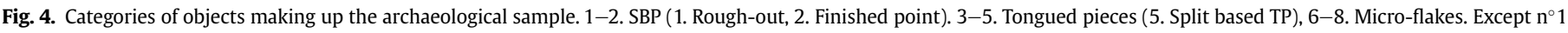
(Blanchard) all pieces are from Castanet. 
distance contacts and/or movements. Graphic imagery on limestone blocks (animals and "vulva") as well as dozens of stone blocks with gouged rings (pierres à anneau) testify to the importance of this small valley to the Aurignacians (Delluc and Delluc, 1978; White et al., 2012; Mensan et al., 2012). While numerous Aurignacian sites have been excavated in SW France in recent decades (La Ferrassie, Le Flageolet, Les Rois, Brassempouy, Abri Pataud, Le Piage, etc.), nothing even approaching the richness and behavioral diversity of the Castel-Merle sites has been observed.

\subsubsection{Choice of archaeological objects for study}

The sample of archaeological material chosen for the current study is comprised of all worked osseous objects with a real or hypothesized relationship to the basal modification of SBP's and/or the production of shims. This sample breaks down into three basic categories of objects (Fig. 4):

1. SBP's, intact or broken, completed or merely roughed out, obviously used or not (Fig. 4.1-2);

2. TP's (Fig. 4.3-5). Although we retain this term for simplicity's sake, it must be understood in its broadest morphological sense. It refers to all objects executed on an antler semicylindrical blank that carry incisions on one end, whether or not such stigmata are bifacial, and whether or not the piece actually bears a tongue. We have excluded from the sample all objects that are clearly linked to other technical operations, such as debris from the reworking or recycling of broken implements and weapons.

3. Micro-flakes less than $30 \mathrm{~mm}$ in length of which at least one face shows a fracture plane. Thus defined, such objects should include any possible shims as identified by Knecht (Fig. 4.6-8).

\subsubsection{Archaeological assemblages studied}

For Abri Castanet, the materials analyzed derive from different episodes in the history of excavations at the site:

1. Peyrony's excavations in the Northern sector of the site in 1911-1912 and again in 1924-1925;

2. Excavations in the Southern sector from 1995 to 1998 by White and Pelegrin and from 2005 to 2011 by White, all of which are housed at the Musée National de Préhistoire, les Eyzies de Tayac (Dordogne);

3. Didon's excavations at Abri Blanchard in 1910-1912, the material from which was dispersed to numerous individuals and institutions in France and abroad. Given this widespread dispersal, which limits our ability to be exhaustive, we have focused our study on the collections housed at the American Museum of Natural History in New York and at the Field Museum of Natural History in Chicago.

A total of 176 pieces was studied, of which 152 objects are from Abri Castanet and 24 from Abri Blanchard (Table 1). The

Table 1

Composition of the archaeological sample studied.

\begin{tabular}{lcccr}
\hline & SBP's & TP'S & Micro-flakes & Total \\
\hline Blanchard (Field Museum) & 3 & 4 & - & $\mathbf{7}$ \\
Blanchard (AMNH) & 14 & 3 & - & $\mathbf{1 7}$ \\
Blanchard total & $\mathbf{1 7}$ & $\mathbf{7}$ & - & $\mathbf{2 4}$ \\
Castanet (north sector) & 56 & 50 & 28 & $\mathbf{1 3 4}$ \\
Castanet (south sector) & 6 & 8 & 4 & $\mathbf{1 8}$ \\
Castanet total & $\mathbf{6 2}$ & $\mathbf{5 8}$ & $\mathbf{3 2}$ & $\mathbf{1 5 2}$ \\
Total & $\mathbf{7 9}$ & $\mathbf{6 5}$ & $\mathbf{3 2}$ & $\mathbf{1 7 6}$ \\
\hline
\end{tabular}

best-represented category is that of SBP's which make up $45 \%$ of the total sample ( $n=79$, Fig. 4.1-2.). For the most part, these are finished pieces, but there are also some rough-outs identifiable by their approximate shape, roughly scraped surfaces and unfinished distal and/or proximal extremities (14 at Castanet and 4 at Blanchard).

The finished points are often fragmentary but the small number of intact or nearly-intact examples show significant size variability (Fig. 5). The length of the intact points from Abri Castanet $(N=14)$ varies from 56 to $176 \mathrm{~mm}$ with a mean of $97 \mathrm{~mm}$. Those from Abri Blanchard $(N=4)$ vary from 53 to $110 \mathrm{~mm}$ with a mean of $76,5 \mathrm{~mm}$. Their "caliber" (maximum width and thickness measured at the meeting of the base and the mid-shaft) is also highly variable. At Abri Castanet $(n=46)$, widths range from 8 to $31 \mathrm{~mm}$ and thicknesses from 4 to $9 \mathrm{~mm}$. At Abri Blanchard $(n=13)$ widths range from 9 to $23 \mathrm{~mm}$ and thicknesses from 5 to $9 \mathrm{~mm}$. Part of this metric variability probably derives from the re-sharpening and repairing of points during their use-lives (Liolios, 1999). However, the presence at Castanet of rough-outs of very different dimensions implies the intentional production of different point sizes.

The morphology of the points is considerably more constant. When intact, the proximal extremity is always ogival in form. The cross-section of the points, subrectangular to oval at mid-shaft, is always flattened with a mean flatness index (width/thickness) of 2,5 for Castanet and 2,3 for Blanchard.

Three sub-types are distinguishable with respect to the alignment of the lateral margins:

1. Lanceolate points. Tapering at the apex with straight, convergent lateral margins and no marked discontinuity between the base and the mid-shaft (18 at Castanet, 7 at Blanchard);

Length of (entire) finished split based points

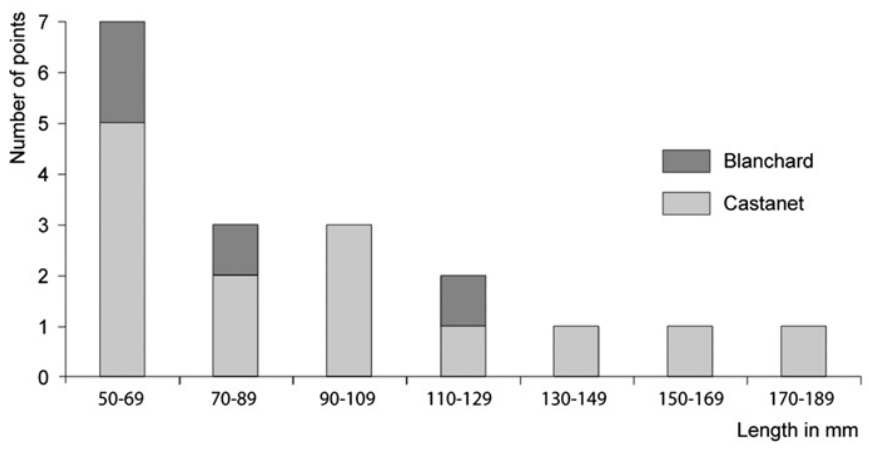

Caliber of finished split based points

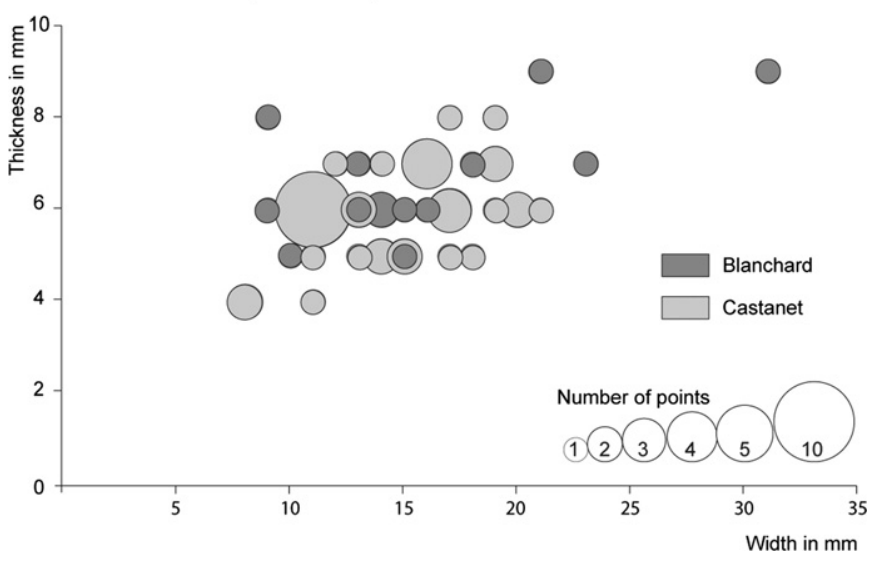

Fig. 5. Dimensions of finished SBP's from Abri Castanet and Blanchard. 
2. Globular points. Slightly convex lateral margins without any marked discontinuity between the base and the mid-shaft (11 at Castanet, 2 at Blanchard);

3. Losange-shaped points. Marked discontinuity or angular bulge between the base and the mid-shaft ( 7 at Castanet, 2 at Blanchard).

TP's represent $37 \%$ of the objects studied ( $N=65,58$ from Castanet and 7 from Blanchard). Roughly half of these can be considered "typical" (26 at Castanet, 4 at Blanchard, Fig. 4.3). The remaining pieces are "atypical" in the sense that they show no tongue and/or have only a unifacial transverse incision (Fig. 4.4). In addition, two pieces from Castanet are unusual in having a split base (Fig. 4.5) .

Finally, micro-flakes (Fig. 4.6-8) are represented only at Abri Castanet and comprise $18 \%$ of the study sample $(N=32) .28$ of these come from the Northern (Peyrony) sector and this number is within 1 of the 27 such pieces identified as shims by Knecht $(1991,1993$, 1997). Nevertheless, it is clear that half of these pieces are, in reality, the broken wings of SBP's (Fig. 4.8). Their dimensions, plano-convex cross-sections, and triangular contours leave no room for doubt. Nonetheless, our attempts to re-fit the points with the broken wings proved unsuccessful. The absence of re-fits can be explained in part by the fragmented nature of the points, many of which show recent fractures on their proximal ends. More experimental work is required to interpret the remaining micro-flakes which show a wide variety of shapes and technical attributes.

Based on the nature of the external (cortical) surfaces of the antler and of the spongy tissue, all of the objects in the sample can be attributed to reindeer antler with the exception of 4 pieces from the North (Peyrony) sector of Abri Castanet, which are in red deer antler (1 SBP, 2 TP's and 1 micro-flake). The dimensions and the morphology of reindeer antler SBP's and TP's along with the thickness of compact tissue observed on them suggest that most of these pieces were extracted from the beam: $90 \%$ exploitation of mediumsized antlers (young male antlers and/or adult female antlers with compact tissue 5-6 mm thick) or large-sized antlers (adult male antlers with compact tissue $\geq 7 \mathrm{~mm}$ thick) (Table 2 ). Only 10 pieces from Abri Castanet could indicate use of smaller antlers.

While we have insufficient data from Abri Blanchard, the most exploited antlers at Abri Castanet were seemingly shed antlers. Nonetheless, in the northern and southern sectors of the site, the archaeological layer yielded two kinds of bases that showed signs of working: bases of large caliber shed antlers and small caliber massacred antlers. It appears then, that the Aurignacians occasionally used small antlers from hunted animals, but more usually they made use of larger shed antlers collected before arriving onsite and/or in the vicinity of the site during occupation (note 5).

\section{Experimental protocol}

Our program of experimental reconstruction took place during the summer of 2012 in the Vallon de Castel-Merle conjointly with excavations at Abri Castanet and Abri Blanchard.

Table 2

Size of antlers used for archaeological SBP's and TP's.

\begin{tabular}{|c|c|c|c|c|c|c|}
\hline \multirow[t]{2}{*}{ Size } & \multicolumn{3}{|c|}{ Castanet } & \multicolumn{3}{|c|}{ Blanchard } \\
\hline & SBP & TP & Both in \% & SBP & $\mathrm{TP}$ & Both in \% \\
\hline Small & 2 & - & 2 & - & - & - \\
\hline $\mathrm{S} / \mathrm{M}$ & 8 & 4 & 10 & - & - & - \\
\hline Medium & 17 & 20 & 32 & 1 & 1 & 26 \\
\hline $\mathrm{M} / \mathrm{L}$ & 15 & 2 & 15 & 1 & 1 & 35 \\
\hline Large & 19 & 29 & 41 & 5 & 5 & 39 \\
\hline \multirow[t]{2}{*}{ Total } & 61 & 55 & & 7 & 7 & \\
\hline & 116 & & & 23 & & \\
\hline
\end{tabular}

\subsection{Experimental raw material}

Our experiments made use of 4 caribou (Rangifer tarandus) antlers from two different Alaskan herds, the Porcupine and the Central arctic herds. All were shed antlers from adult males, collected in October and November, 2011 in the vicinity of the Brooks Range. The antlers are large, well developed and show very thick layers of compact tissue (Fig. 6). Along the beam, compact tissue thickness ranges from $6 \mathrm{~mm}$ high up (base of the palmate crown) and $14 \mathrm{~mm}$ further down (just above the uppermost tine). It is even thicker at the level of the basal tines, ranging from 9 to $12 \mathrm{~mm}$ at the bez tine and up to $15-16 \mathrm{~mm}$ at the brow tine.

To facilitate shipping, the antlers were saw-cut at the middle of the beam (at the level of the guard tine) and at the base of the palmate crown and the tines were removed (Fig. 6). We therefore began our experiments with pre-cut sections of antler, but only the beam was used.

\subsection{Fabrication of rough-outs for SBP's}

\subsubsection{Production of blanks}

Although flaking of reindeer antler by direct percussion is known in the Aurignacian (Pétillon, in press; Tartar, 2012), separating antler into sections is the most frequently observed procedure. It consists in chopping the antler beam perpendicular to its long axis in order to extract roughly cylindrical segments and then to split these by use of wedges to obtain semi-cylindrical blanks (baguettes in French) (Knecht, 1993; Liolios, 1999; Tejero et al., 2012).

To save time, our experimental blanks were created using modern tools (hacksaw and steel wedges). However, two beam segments were created using tools available to the Aurignacians (Fig. 7). These were two beam segments that retained the antler base but which had been sawed at the other extremity to facilitate shipment from Alaska. Using a large flint flake in handheld percussion, a groove was created by chopping around the circumference of each segment just above the brow tine in order to remove the antler base (Fig. 7.1). Once about $3 / 4$ of the thickness of the compact tissue had been removed in this fashion, the bottom of the groove was deepened by circum-incision. Striking the now weakened segment against a large rock resulted in the detaching of the antler base leaving behind a saw-tooth fracture plane at the center of the beam (Fig. 7.1). Two opposing longitudinal fissures were then initiated in the axis of the saw-tooth fracture by placing the extremity of the segment on an anvil and tapping its surfaces using a stone cobble. Inserting a wooden wedge by indirect percussion prolonged the fissures and resulted in a first semi-cylindrical blank (Fig. 7.2.). Repeating this procedure, from this same extremity or from the opposite one, allowed us to produce 6 semi-cylindrical blanks.

In total, the reduction of the beam segments yielded 49 semicylindrical blanks of which 43 were chosen to be transformed into SBP's or shims and 3 to serve as wedges for producing semicylindrical segments or for cleavage of SBP bases.

\subsubsection{Reducing the semi-cylindrical segments into SBP pre-forms}

The shaping of a SBP involves three main steps (Knecht, 1991, 1993; Liolios, 2006; pers. obs.): (1) pre-forming which involves sizing the piece, removing most of the spongy tissue on the underface, smoothing and rendering convergent the sides of the now flattened antler segment; (2) creating the basal split; (3) final shaping and finishing.

Since such splitting and wedging does not result in highly standardized blanks, pre-forming requires the removal of a large amount of raw material. To better accomplish this, the semi-cylinders were 


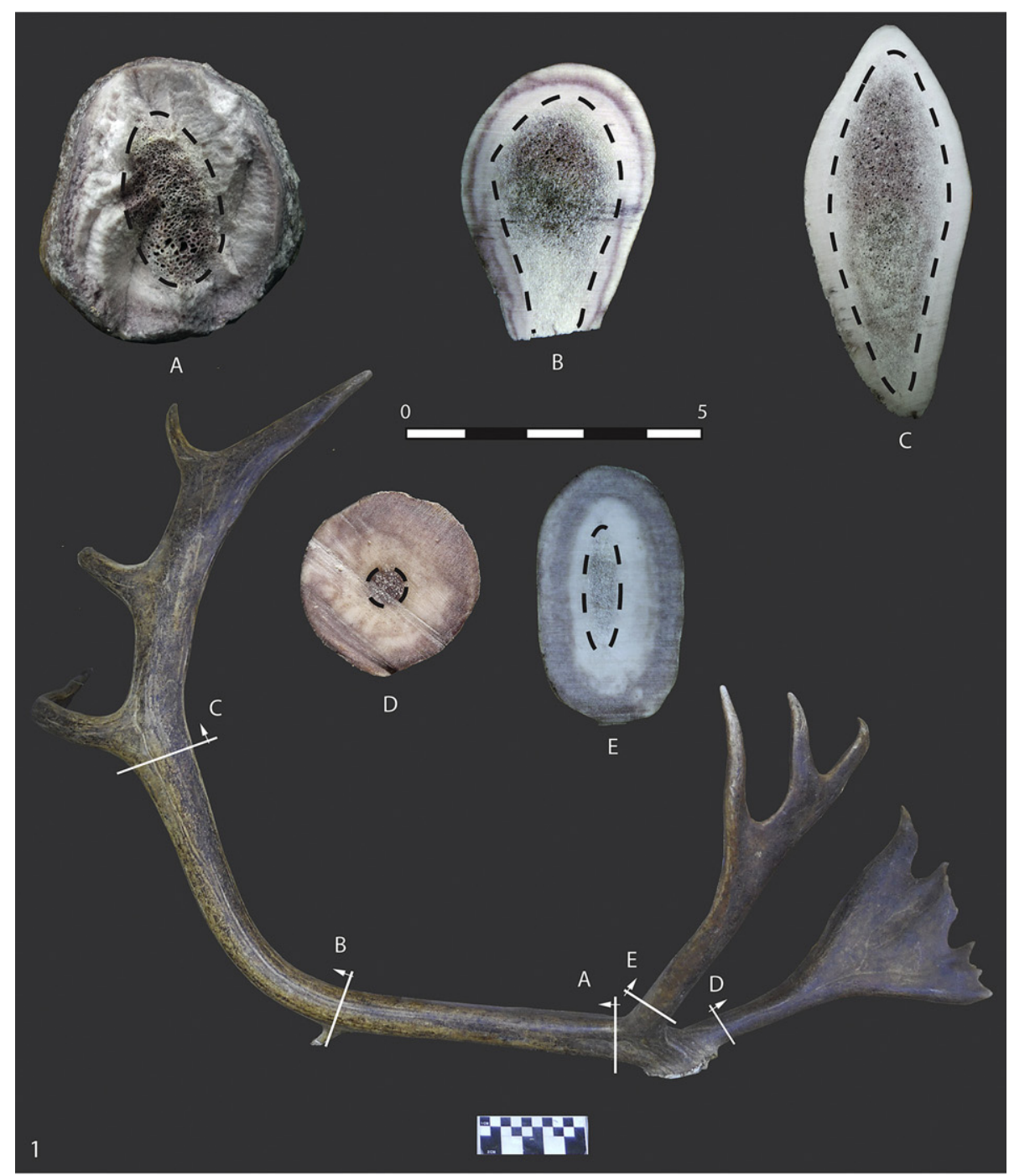

2 \begin{tabular}{l|c|c|c|c}
\multicolumn{1}{c|}{ zone } & antler 1 & antler 2 & antler 3 & antler 4 \\
\hline A - beam, base & - & - & 14 & 10 \\
\hline B - beam, center & 7 & 8 & 6 & 7 \\
\hline C - beam, top & 4 & 5 & 4 & 4 \\
\hline D - brow tine & - & 15 & 16 & - \\
\hline E - bez tine & 9 & - & 10 & 12
\end{tabular}

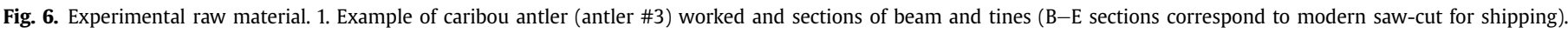
2. Thickness of antlers' compact tissue (in $\mathrm{mm}$ and per zone).

systematically soaked in water, a well known technique to soften osseous materials (Feustel, 1973; Billamboz, 1977; Newcomer, 1977; McGregor, 1985; Provenzano, 2001 among others).

The lithic implements used in our experimentation were chosen from a broad range of Aurignacian-type tools and debitage knapped “on-site" by F. Le Mené, an experienced flintknapper. With the exception of end-scrapers on blades, most lithic pieces used for transforming the semi-cylindrical segments into pre-forms were selected from knapping bi-products and rejects rather than formal tools. Crested blades, used in hand-held percussion, proved very effective for the removal of spongy tissue and the smoothing of the lateral margins of semi-cylindrical segments. For finer work, crested blades were also used as were blade cores, broken blades and rejuvenation tablets, both in passive and active mode (Fig. 7.3).
All of these lithic pieces had in common the fact of possessing sharp yet resistant edges and angles. The use of end-scrapers on blades possessing convex scraper fronts was limited to the removal of spongy tissue from the inferior face of the semi-cylindrical segments (Fig. 7.3). All of these different kinds of flint pieces are represented in the lithic assemblage recovered during excavations at both Abri Castanet and Abri Blanchard (Didon, 1911a; Peyrony, 1935; L. Chiotti and C. Cretin pers. com.).

\subsection{Creation of the basal splits}

The two main hypotheses currently in play were tested: 1) The Knecht hypothesis: splitting of bases by cleavage and the manufacture of shims (leaving behind TP's as waste products) for 


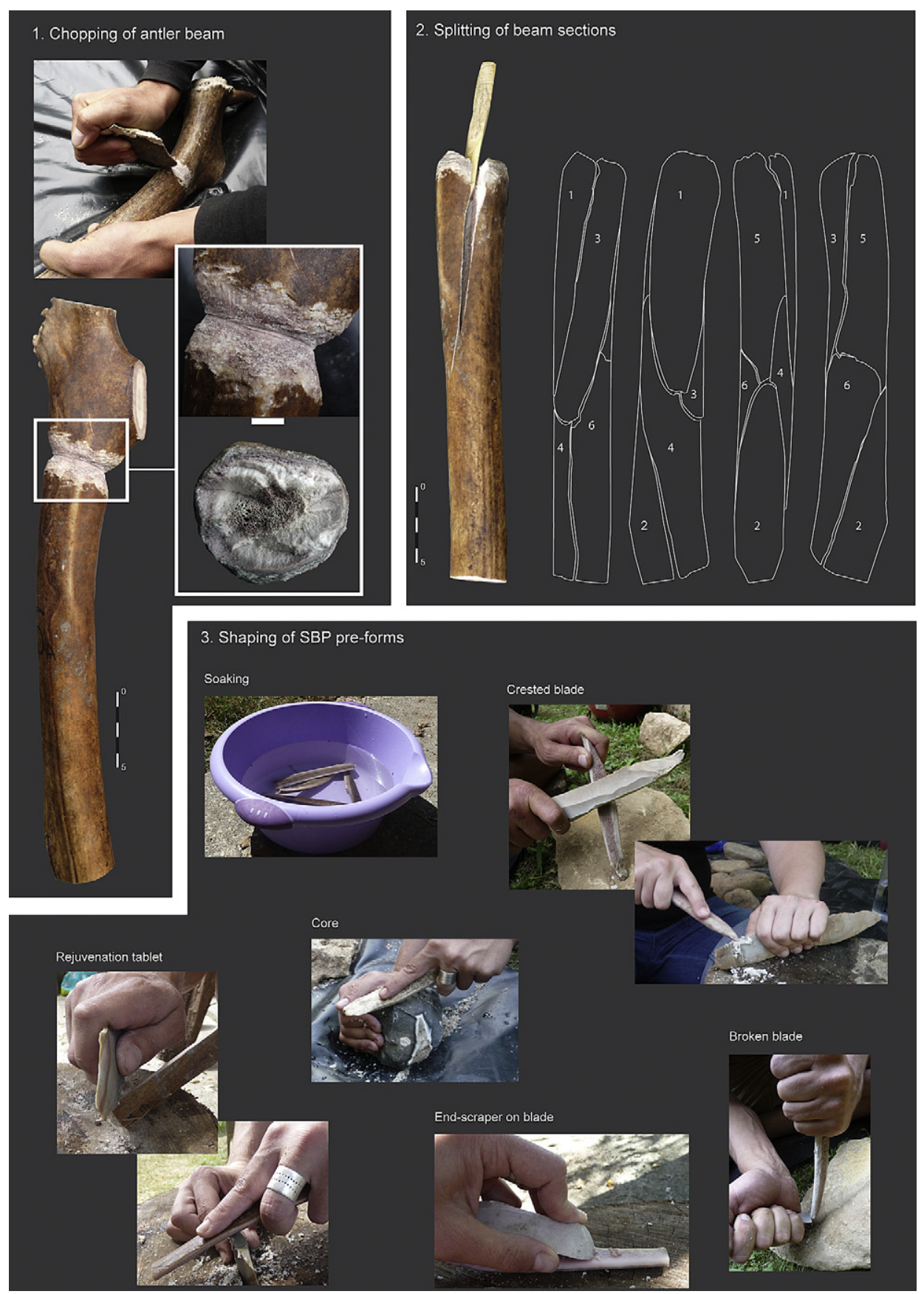

Fig. 7. Debitage and preforming of experimental SBP's.

insertion between the wings of SBP's. 2) The Peyrony hypothesis according to which SBP's were extracted by transverse incision and flexion.

\subsubsection{The Knecht hypothesis}

4.3.1.1. Cleaving the bases. Cleavage of bases was attempted on four pre-forms at different stages of preforming (Fig. 8.1). For three of them, a portion was detached by peripheral incising and proximal flexion so as to create a regular and slightly hollowed out or spiculate cleavage platform in the center of the piece in order to provide a point of purchase for a wedge (Fig. 8.3 and 5). The base of the third semi-cylindrical segment was entirely preformed by scraping and abrasion (Fig. 8.2).
In both situations, cleavage proved to be a delicate operation. Reindeer antler is highly resistant and the wedge degrades quickly: flint wedges (fragments of unretouched blades, rejuvenation tablets) shattered very quickly and the working end of wood and antler wedges rapidly compressed and had to be reworked. On one of the points with an incised base we tried to initiate lateral fractures, placing the proximal end of the SBP pre-form on an anvil and tapping the edges with a stone cobble. However, the fractures thus obtained were oriented obliquely to the long axis of the piece (Fig. 8.4-5). Persisting with this approach, we were in the end able to split the end of the three other pre-forms without ever succeeding in controlling the orientation of the fractures, which quickly deviated toward one face or the other (Fig. 8.2-3). 


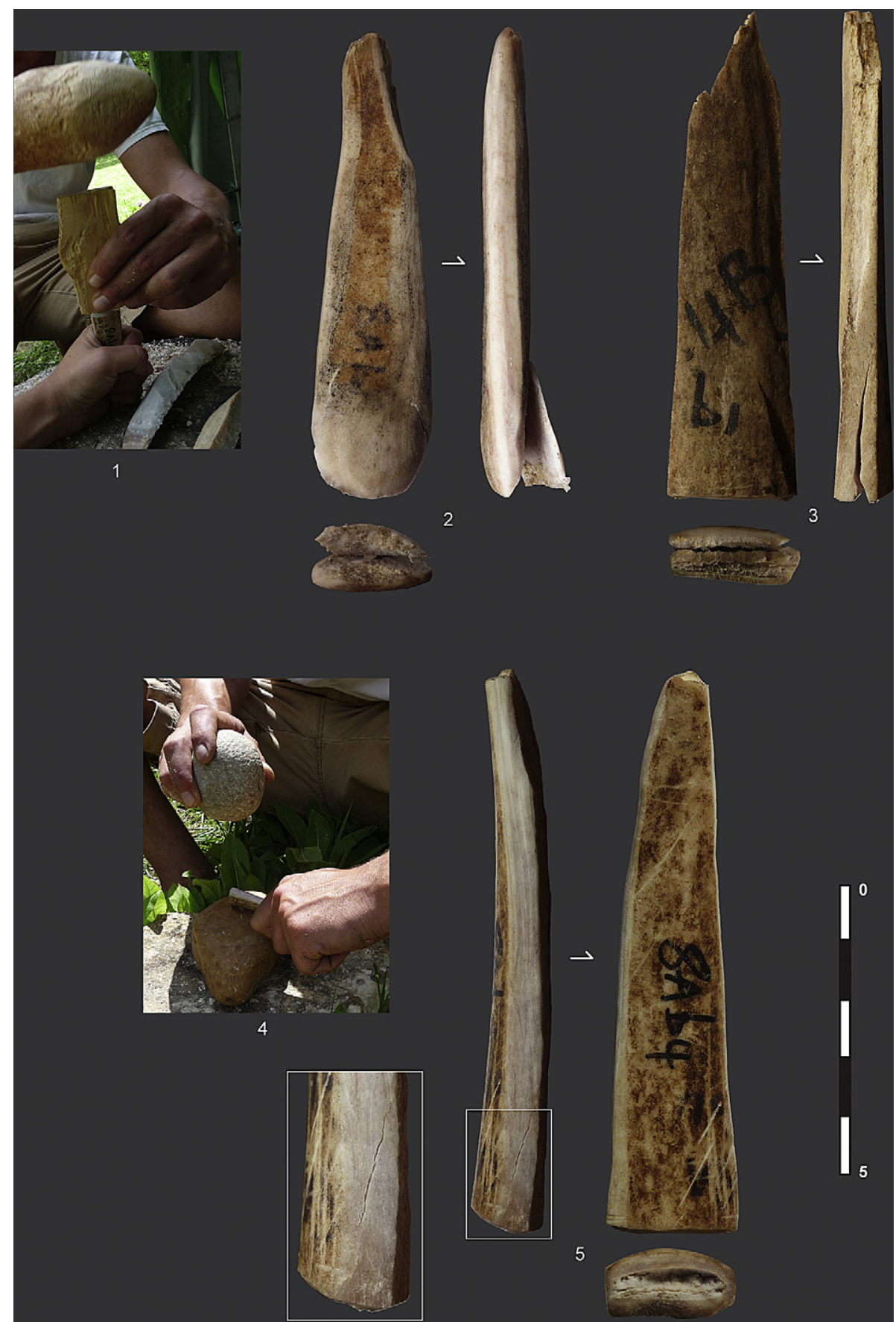

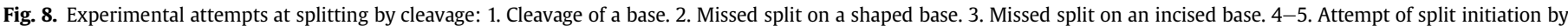
lateral percussion.

From these attempts, we concluded that, while modification by simple cleavage may be possible, it is extremely difficult to achieve.

4.3.1.2. Producing shims. Following the operational sequence proposed by Knecht $(1991,1993)$, a fragment of semi-cylindrical segment was shaped on its underface and lateral edges to give it a quadrangular section (Fig. 9). While it was never specified in Knecht's scheme, a small mass of material was detached from the distal end by peripheral incising followed by flexion. This procedure is required in order to extract shims. Two transversal incisions, $2-3 \mathrm{~mm}$ deep, were created on the superior and inferior faces at a point $15 \mathrm{~mm}$ from the distal end. As for the SBP's, the production of shims requires cleaving, the difference here being that the cleavage has to be executed about a third of the way through the thickness of the piece (as measured from the superior and inferior surfaces of the blank) so as to intersect with the pre-existing incisions. We were able to produce a first generation of shims but with the same difficulties as those encountered in the cleavage of the SBP bases (damage to wedges, difficulty in initiating the split and in controlling its trajectory). After removing the residual tongue and repetition of the partial incision across the two faces, we were able to extract two more shims (Fig. 9). The operational chain proposed by Knecht for the production of shims was indeed replicated but, as for the cleavage 


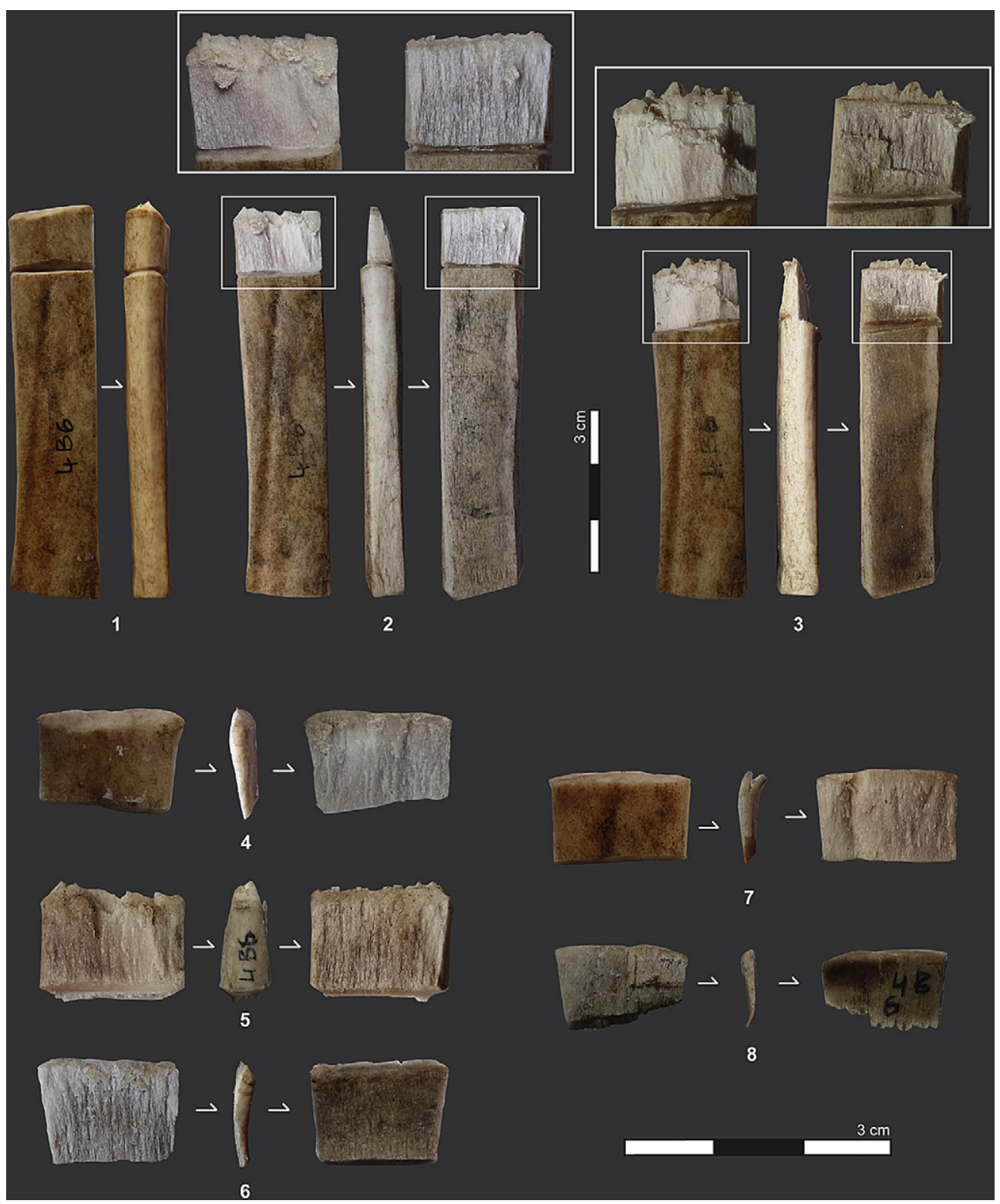

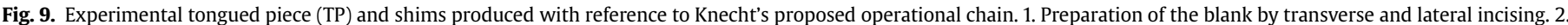

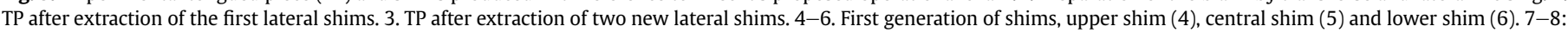
second generation of shim, upper shim (7), lower shim (8).

of SBP bases, is exceedingly delicate to reproduce due to the resistance of the material.

4.3.1.3. Comparisons with the archaeological assemblages. As many authors before us have noted (e.g., Leroy-Prost, 1975; Newcomer, 1977), it is nearly impossible to determine the procedure used to create SBP bases by only studying the points themselves. We were also able to observe experimentally that basal cleavage leaves few stigmata on the points. As a result, we chose to limit our comparisons to TP's and shims.

There are sharp differences between the TP's obtained by experimentation and archaeological examples. On the tongued pieces created by shim extraction, we observed that the faces of the tongue itself are irregular and show light markings from the insertion of the wedge (Fig. 9). Moreover, the split never reached the bottom of the incisions but deviated near the upper margin of the incision or well before reaching it. Consequently, splitting leaves residual incisions on the faces of the central tongue which are characteristic of extraction by cleavage departing from the distal end. However, such stigmata are totally absent from archaeological pieces where all tongues (when they are present) have faces that are perfectly smooth and free of technical traces (Fig. 10).

The experimental shims are also very different from the archaeological micro-flakes. The experimental examples show residual incisions at both ends with, for lateral shims, a scraped surface (corresponding to the scraped interior or exterior face of the blank) opposite to a fracture plane and, for central shims, two opposing fracture planes (Fig. 9). In the archaeological sample of micro-flakes (including the pieces illustrated as shims by Knecht), not a single example shows residual incisions at both ends or two opposing fracture planes (Fig. 10). In the end, we followed precisely the procedure hypothesized by Knecht but, surprisingly, the resulting products do not resemble the archaeological examples. 


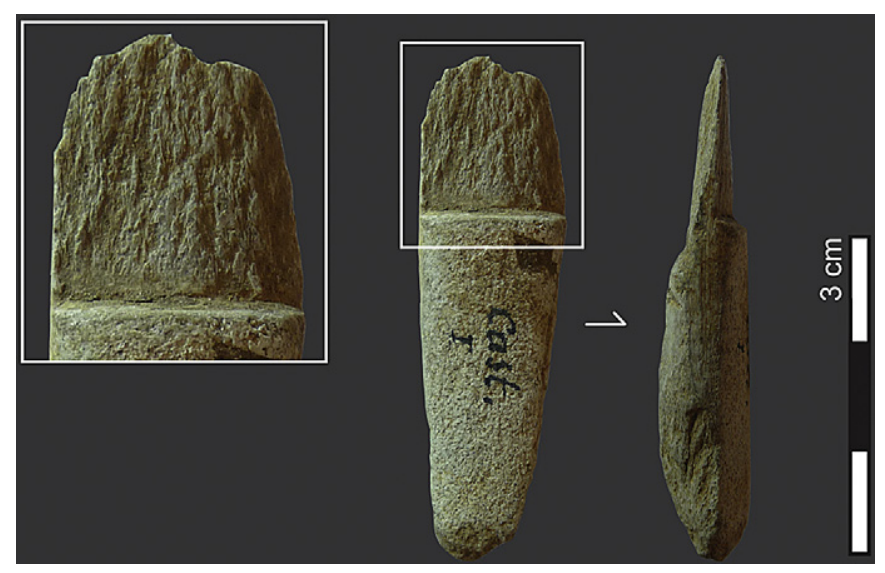

Fig. 10. Details of the tongue of an archaeological TP (Castanet).

Certain archaeological micro-flakes with residual incisions at one end could possibly be compared to the final experimental shim resulting from an important deviation of the split (Fig. 9.8). However, no archaeological TP's show this kind of accident. We conclude strongly from these comparisons that the archaeological TP's cannot have served for the production of shims.

\subsubsection{Peyrony's hypothesis revisited}

The procedure for creating SBP's proposed by Peyrony is based on the cutting of a transverse incision into the two faces of the blank followed by back-and-forth flexion so as to extract a TP in order to produce a split at the base of the point-to-be. We have experimented with this method on 39 blanks, with 1-4 attempts per blank. In total, 69 tests were undertaken which allowed us to refine the sequence and type of gestures required to ensure success.

4.3.2.1. Initiating the split. The flexibility of the blanks and the use of a system of chocks were essential to a successful split. When they are derived from shed antlers (thus dry), the pre-forms are very rigid and it is difficult to bend them without snapping them rather abruptly. As noted above, soaking in water softens the material (Feustel, 1973; Billamboz, 1977; Newcomer, 1977; McGregor, 1985; Provenzano, 2001) and thus renders the pre-forms more supple and tolerant of flexion. Several days of soaking are required to obtain a satisfactory result but soaking in hot water accelerates the process. However the blanks cannot be too thick; soaking has little effect on blanks with a thickness of more than $8 \mathrm{~mm}$.

The use of chocks is mandatory since pre-forms, even when soaked, require a force to bend them that exceeds that which can be accomplished with bare hands as implied by Peyrony (Fig. 1.1). Moreover, when hand-held, the pre-forms must be grasped, one hand at each end and must, therefore, be transversely incised in the middle. However, the majority of archaeological TP's are much too short to imagine holding them in such a position. As a viable alternative, we opted for insertion of the pre-forms into a split in the transverse section of a log. This approach to chocking allowed us to firmly immobilize the base of the pre-forms and to keep both hands free for flexion. Stabilized, when required, by wooden or antler wedges, this kind of fixation can be easily adapted to different pre-forms volumes.

Different operational chains were attempted, in incising and bending operations and the order in which they were employed. One particular operational chain stands out, broadly consistent with that suggested by Nuzhnyi (1998). It is comprised of four basic steps (Fig. 11): (1) partial transverse incising of the base of the preform on its superior face (2) bending of the pre-form toward the

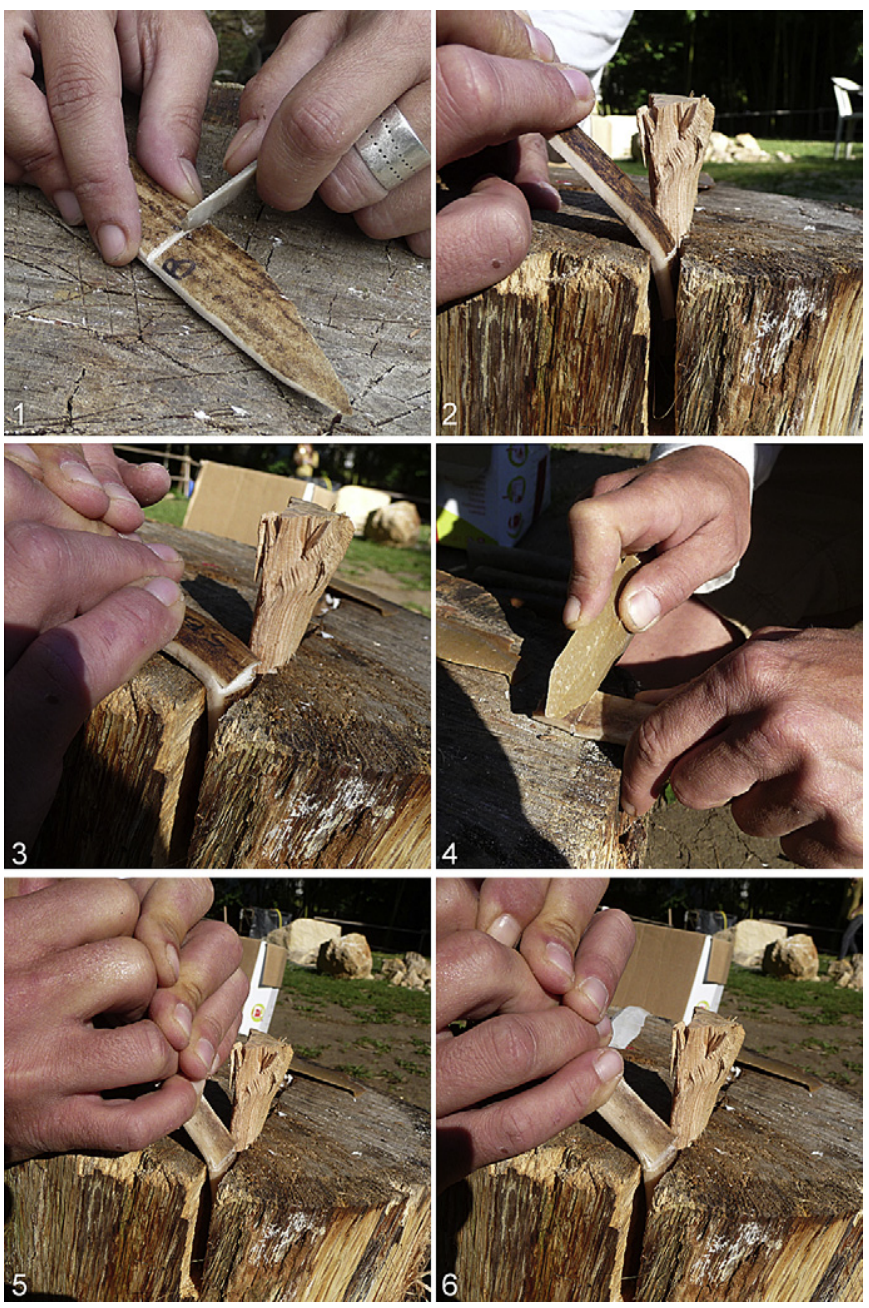

Fig. 11. Experimental replication of splitting by incision and flexion, 1. partial transverse incising of the base of the pre-form on its superior face, 2-3. flexion of the preform toward the inferior face and production of a fissure, 4. transverse incising of the inferior face of the pre-form, 5-6. flexion of the pre-form toward the superior face and production of a second fissure.

inferior face, (3) transverse incising of the inferior face of the preform, (4) flexion of the pre-form toward the superior face. The detailed procedure can be described as follows:

1. The pre-form is incised to a depth of approximately one third of its thickness using the cutting edge of an unretouched blade, but the incision is often broadened using the dihedral angle of the fracture surface of a broken blade (Fig. 11.1).

2. The base of the pre-form is immobilized in the split in the log in assuring that the broadened incision is situated a few millimeters above the surface of the log (Fig. 11.2). The protruding part of the pre-form is taken in both hands and is bent gradually backward (in the direction of the inferior face). The positioning of the incision above the surface of the log situates the zone of maximum bending slightly above the incision and allows bending of the pre-form without risk of unintended breakage at this location. Such bending of the osseous fibers propagates a fissure extending from the bottom of the incision in the direction of the medial portion of the blank, and across its entire width (Fig. 11.3). In some cases, a wedge inserted behind the pre-form allows one to raise the maximum flexion point and helps to lengthen the fissure without risk of breakage. 
3. A second incision is created on the inferior face and edges of the pre-form at the same level as, or slightly above that of, the preceding incision (Fig. 11.4). If there is residual spongy tissue on the inferior face, it is imperative that the bottom of the incision reaches the compact tissue to allow the propagated fissure to penetrate the latter.

4. The base of the pre-form is once again immobilized in the split of the $\log$ and bent forward this time (Fig. 11.5).

At this point, different outcomes are possible depending upon the thickness of the blank, its flexibility or the orientation of the propagated fissure. Repeating the same procedure as before (maximum flexion point situated just above the incision) creates a new fissure beginning at the new incision (Fig. 11.6). If the two fissures are oriented slightly obliquely, the flexion of the blank will cause them to meet. In that case, the base of the point-to-be has a $\mathrm{V}$-shaped split and the waste product a tongue with a thin extremity (Type A modification) (Fig. 12). This procedure, which is very close to that reconstructed by Nuzhnyi (1998), is also that which most closely resembles the Peyrony hypothesis. If the two fissures propagate parallel to each other, the waste product must be extracted by flexion and/or torsion. The base of the point-to-be will have a U-shaped split with a saw-tooth bottom and the waste product will have a tongue with a denticulate extremity (Type B modification) (Fig. 12). In both cases, the waste products are classic TP as known from the archaeological record.

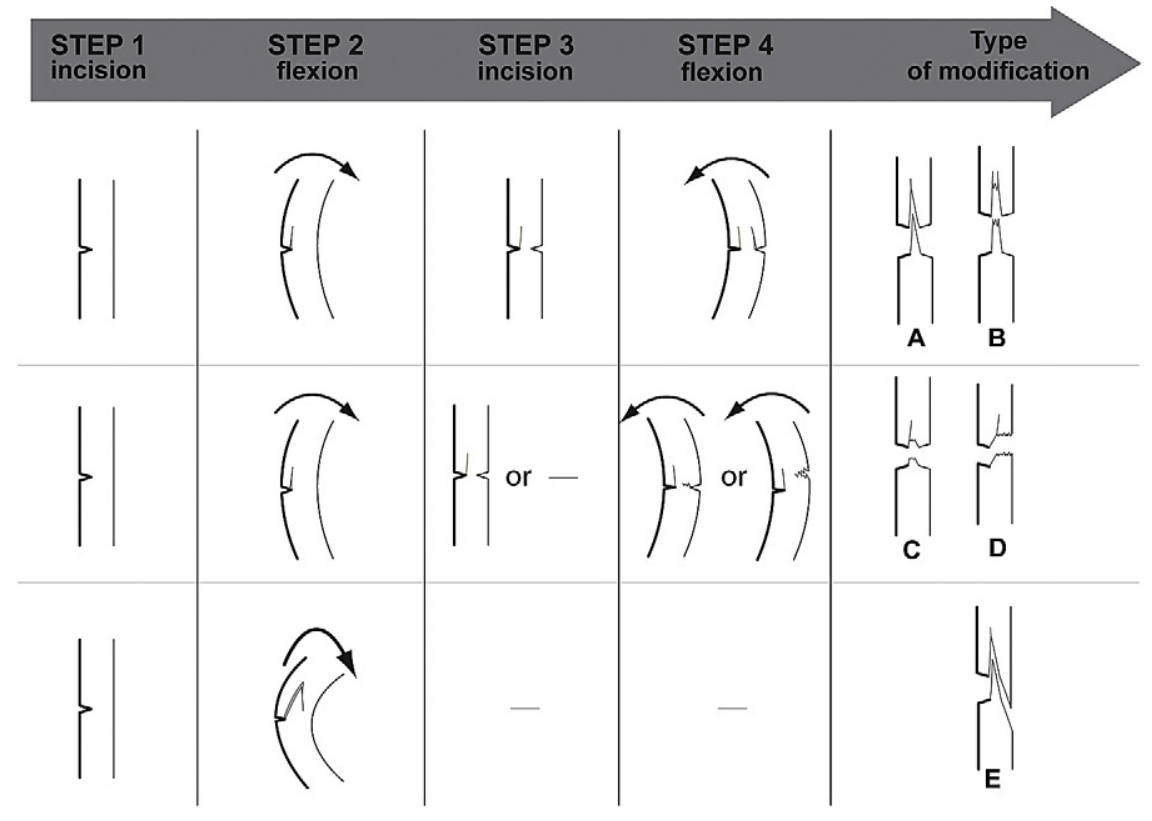

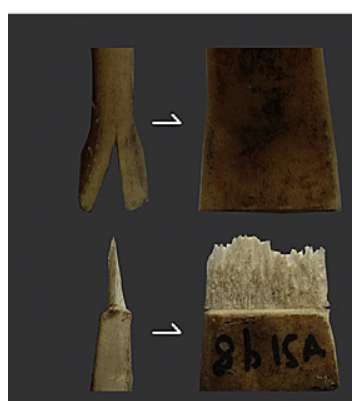

A

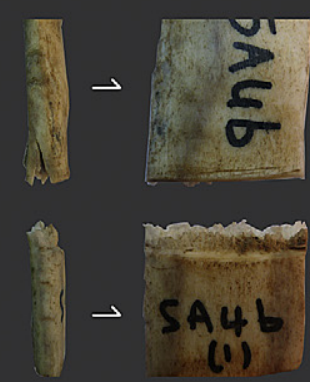

D

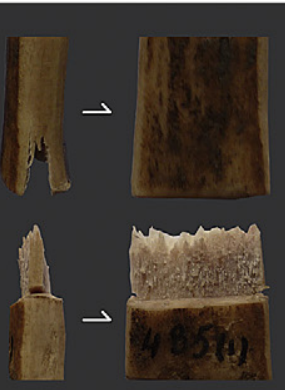

B
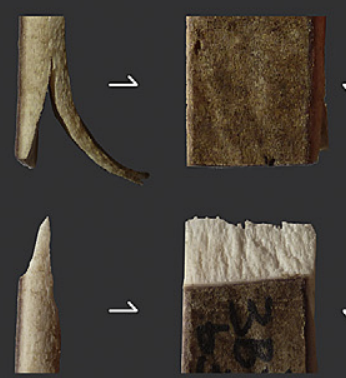

E

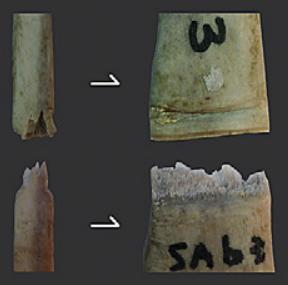

C

Fig. 12. Operational chain of basal splitting by incision and flexion. Operational variants and typology of experimentally obtained extremities. 
The creation of a second fissure is not mandatory as long as the first is close to the center of the pre-form. If such is the case, the remaining bridge connecting the pre-form to the future waste product can be cut through completely, or even partially if strong flexion is applied to separate the two elements. At this stage, the base of the roughed out point shows a very fine split since no material has been removed and the waste product is not tongued (Type C modification) (Fig. 12). This procedure is in line with the second one suggested by Nuzhnyi (1998) and that reconstructed by Pétillon based on two SBP rough-outs from the grotte des Hyènes at Brassempouy (Pétillon, in press). On these two pieces for which the wings conjoin perfectly, the wing situated on the inferior face of the piece shows a residual incision on its internal face suggesting that a second incision was produced from the superior face of the pre-form (in continuity with the first transverse incision).

If the pre-form is not very thick, a second transverse incision is not even necessary and the extraction can be accomplished by simple flexion. The base of the point-to-be and the associated waste product will have a residual incision on one side and a saw-tooth fracture plane on the other, directly opposite each other or slightly offset (Type D modification) (Fig. 12).

A final alternative is also viable for very supple pre-forms. During the initial flexion these can be bent gradually to nearly $180^{\circ}$ which propagates a $\mathrm{V}$-shaped fissure. The base of the point-tobe and the waste product are similar to those from Type A modification, the sole difference being that they show a ripping/tearing surface on the inferior face (Type E modification) (Fig. 12).

4.3.2.2. Lengthening the split and finishing of the point. The ultimate step consists of giving the point its final form (Fig. 13). In the mesio- distal portion, the faces and lateral edges are smoothed and the end is pointed and centered on the axis of the blank by scraping, using the same tools with unretouched edges used in the initial pre-forming (core tablets, unretouched blades, etc.). In the proximal portion, flexion to create the split often produces a significant outward curvature of the wings that is difficult to straighten. To bring the bases into conformity with what we see archaeologically, we eliminated the curved extremity by scraping and/or by abrasion on a sandstone grinder (removal of $10-15 \mathrm{~mm}$ in the most extreme cases). Abrasion proved more efficient than scraping and had the advantage of giving a rounded form to the point bases.

Removing the curvature of the wings shortens the splits to the point that they have to be lengthened. To do this, very thin wedges of reindeer antler were inserted between the wings by gentle tapping; in other words, by cleavage. The split having already been started, this operation is quick and easy. It is usually done more than once in the course of shaping, modifying and finishing the proximal end (Fig. 13). If, in the beginning, there was material missing from between the wings, all trace of such absence is lost during the reconfiguration of the proximal end. On finished points, the internal surfaces of the split re-fit perfectly with little or no space between them (Fig. 13).

4.3.2.3. Failures and mishaps. In order to successfully reproduce the modification of SBP bases by incision and flexion a certain number of rules have to be followed relating to the varying suppleness of the pre-form (amount of time soaked, thickness of the blank), to the type of incision (location, depth), to the kind of flexion applied (degree of bending, chocking) and to the order of constituent actions. Before mastering these different

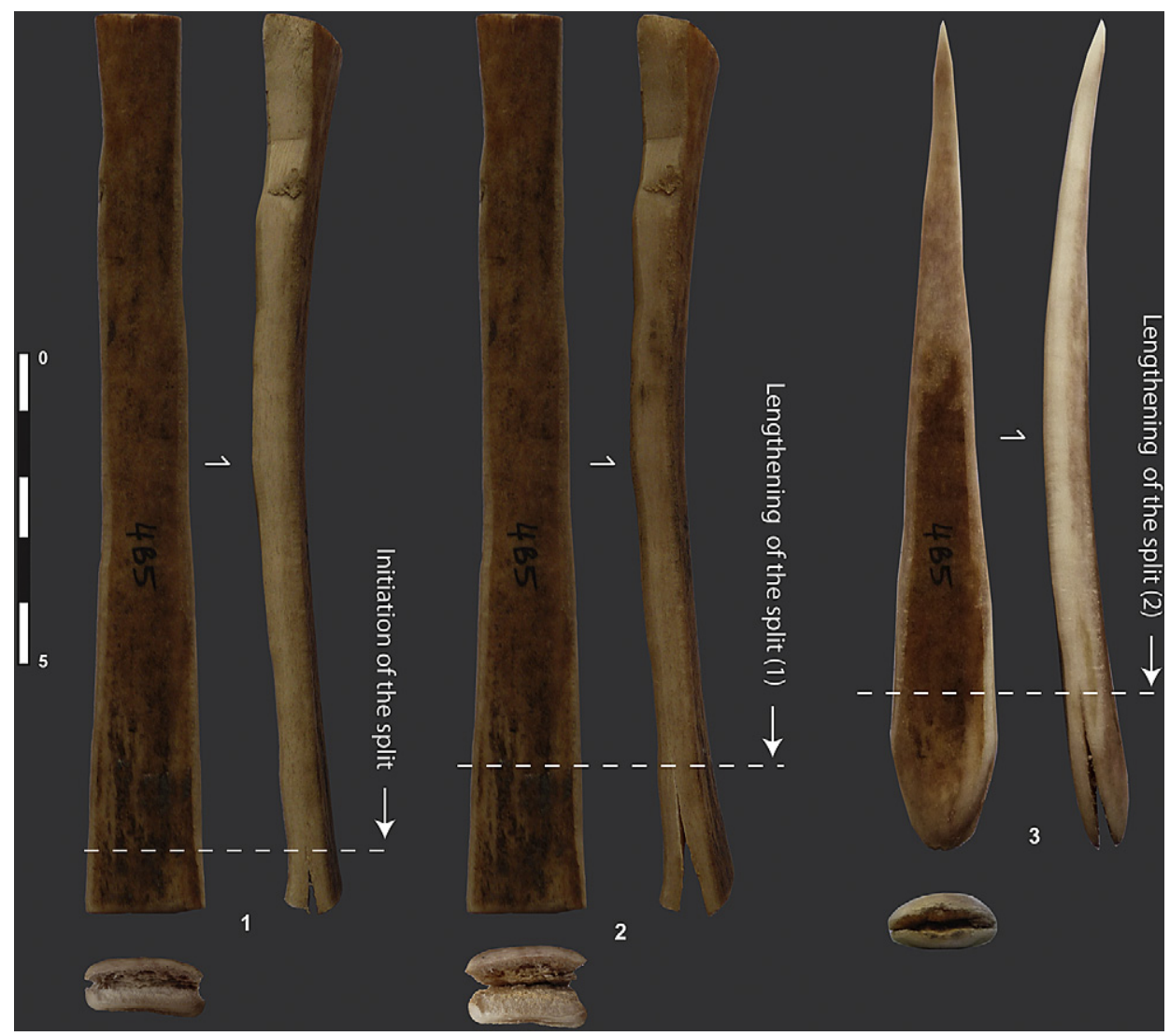

Fig. 13. Finishing of split based points: Lengthening the split and final shaping of the points. 
parameters, we experienced a number of failures. The primary cause of these was insufficient flexibility of the pre-forms resulting in breakage during flexion without ever initiating a fissure. The resulting fractures show a stepped or beveled (simple or double) morphology. In the case of double beveled fractures, characteristic triangular flakes are produced (Fig. 14). Flexing of the blank after creating an incision across the superior and inferior faces was also attempted on numerous occasions but usually results in a saw-tooth break. It is worth noting that some of the waste products of these failures are similar to those created during the successful production of split bases (such as waste products with a stepped fracture plane and those of Type D; waste products with saw-tooth fracture plane and those of Type C).
Accidents can also occur during lengthening of the split. This happens when the split is not exactly parallel to the long axis of the blank. In sum, it is difficult to re-orient even a slightly oblique split when attempting to lengthen it. The split plunges to one face or the other and ends up detaching a flake (Fig. 15). Lengthening of the split is also subject to mishaps when it is positioned lateral to the central axis of the point-to be (Fig. 15).

4.3.2.4. Comparison with archaeological materials. In contrast to what we saw when following the Knecht hypothesis, the correspondence here between experimental and archaeological pieces is evident.

We note in particular two SBP pre-forms, one from Castanet and the other from Blanchard, on which the proximal portion of the
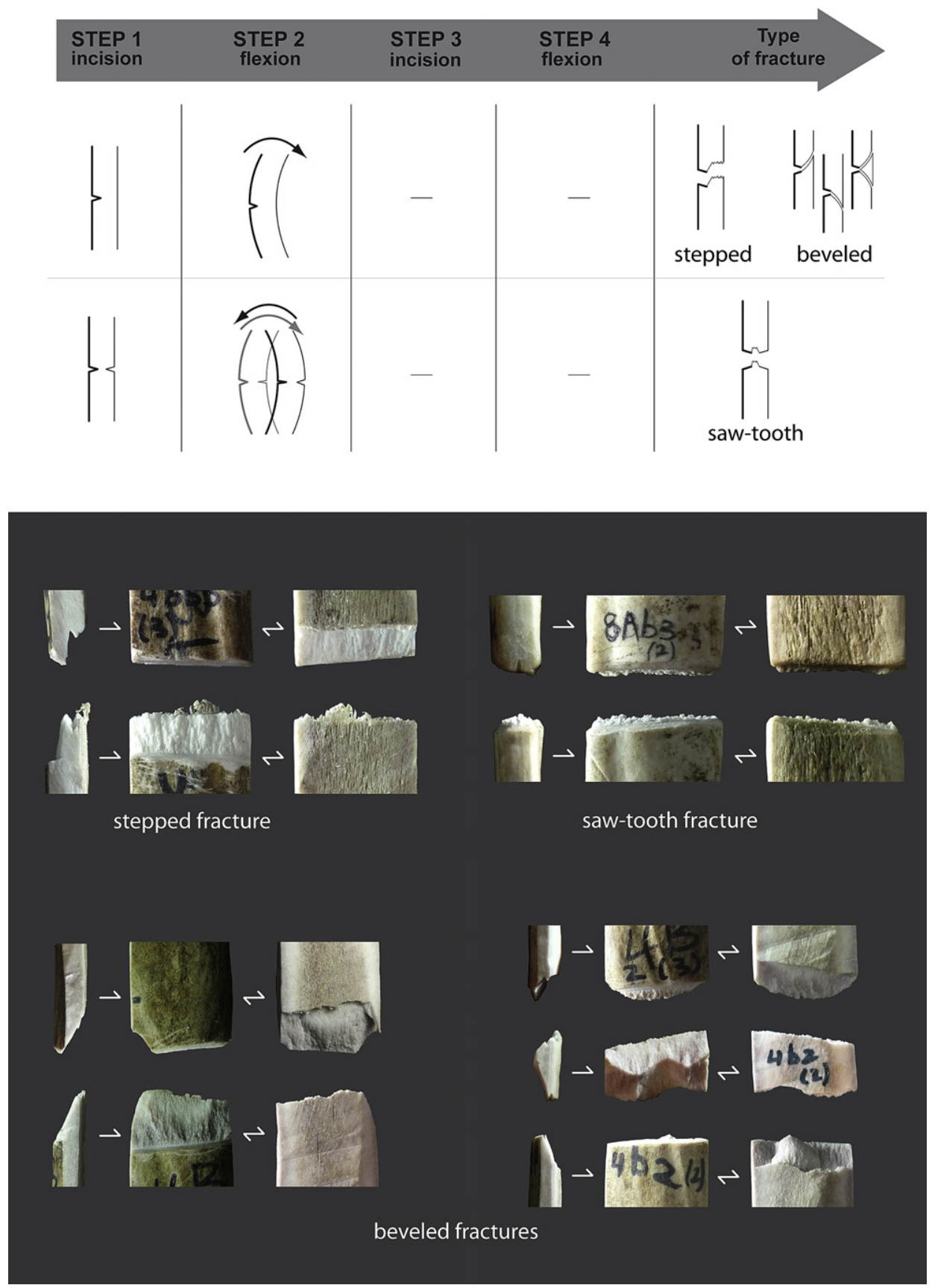

Fig. 14. Experimental failures that occurred during splitting by incision and flexion. Operational variants and typology of experimentally obtained extremities. 


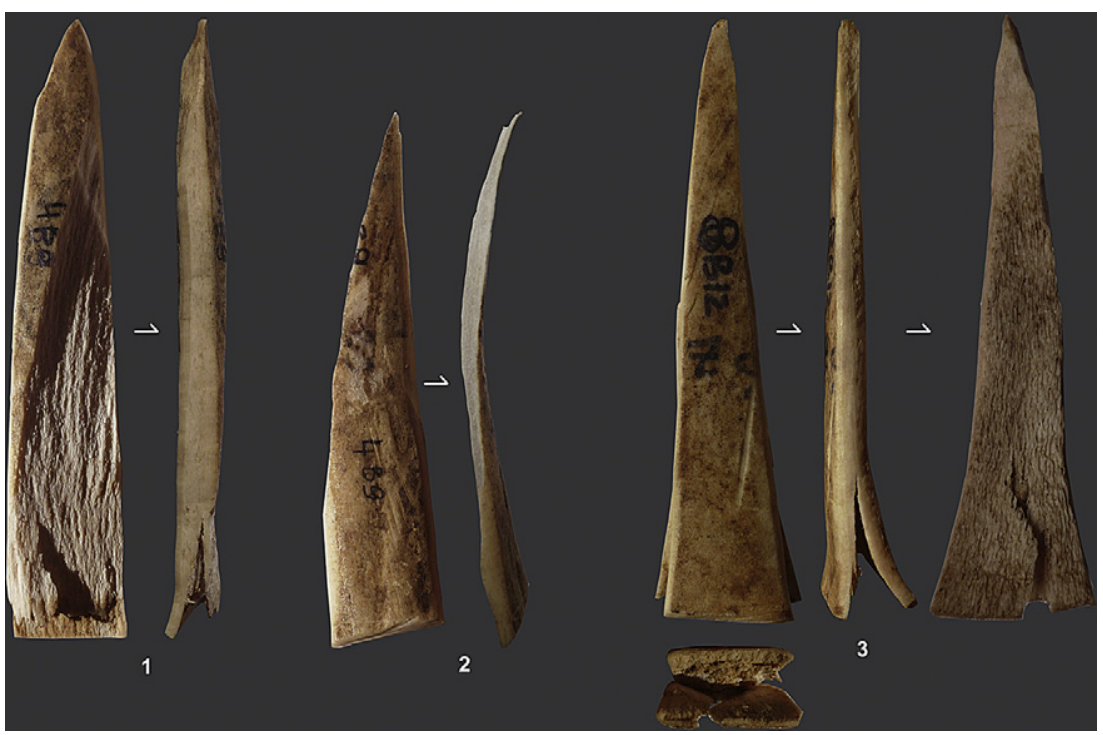

Fig. 15. Experimental mishaps during lengthening of the split.

superior face shows a transverse incision reminiscent of the first step in the initiation of a split, but prior to flexion (Fig. 16.1). However, more than other archaeological pieces, a SBP pre-form from the Southern sector of Abri Castanet is emblematic of modification by incision and flexion (Fig. 16.2). With a length of $225 \mathrm{~mm}$, the piece in question was crudely shaped by scraping and was transversely incised on its superior face a few millimeters above the proximal end. The zone just above the incision on the superior face is missing, but the piece clearly shows the beginning of a split initiated at the incision and extending toward the mesial region. The fracture surface shows the residual bottom of the incision, of which only the inferior surface is preserved. This attribute is found on all waste products created by experimentation based on incision and flexion and matches our observations on archaeological pieces. There is little doubt that this rough-out is the result of the first two steps of producing a split by incision and flexion. Until now, no piece of this kind had been described with the possible exception of an object attributed to the Early Aurignacian (layer 11) at Abri Pataud, part of a re-fit between a SBP and a TP (Vercoutère, 2004; Chiotti et al., 2003: 188).

Otherwise, numerous archaeological rough-outs and waste products give witness to the 5 types of basal modification that we identified experimentally (Fig. 17):

\section{Type A modification}

A roughed out SBP from Abri Blanchard shows a V-shaped basal split with the wings curved outward. There is material missing between the wings. The distal extremities of the latter retain residual incisions. No corresponding waste product (with bifacial incision and a thin central tongue) has been identified in the Blanchard assemblage but there are 10 from Abri Castanet.

\section{Type B modification}

A roughed out SBP from Abri Castanet is identical to that described above, with the difference being that it has a U-shaped split with a saw-tooth bottom. At least 9 waste products from Abri Castanet and 3 from Abri Blanchard show bifacial incision and a central tongue with a denticulate extremity and can therefore be attributed to this type of modification.

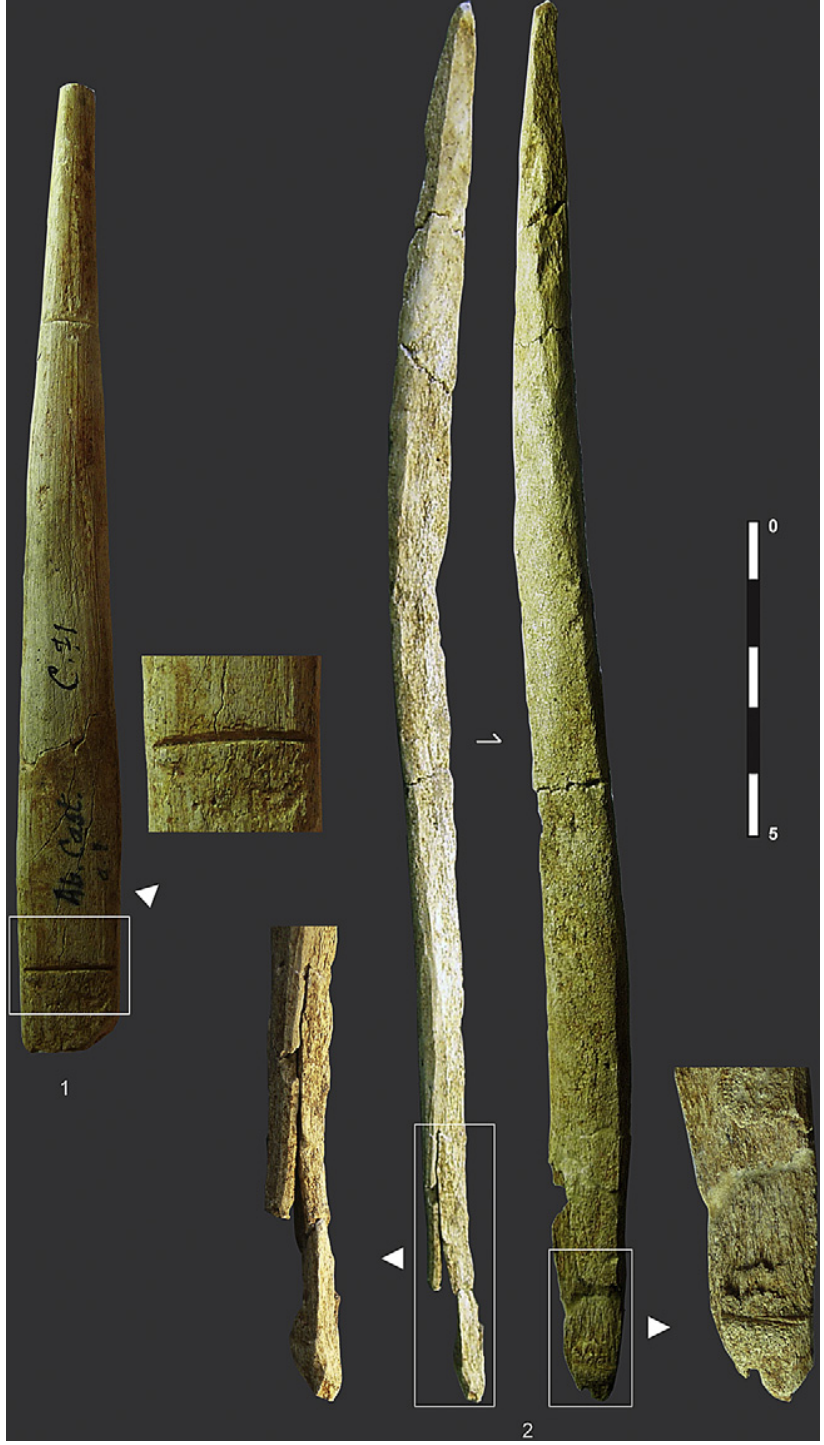

Fig. 16. SBP preform and SPB rough-out illustrating splitting by incision and flexion (Castanet). 


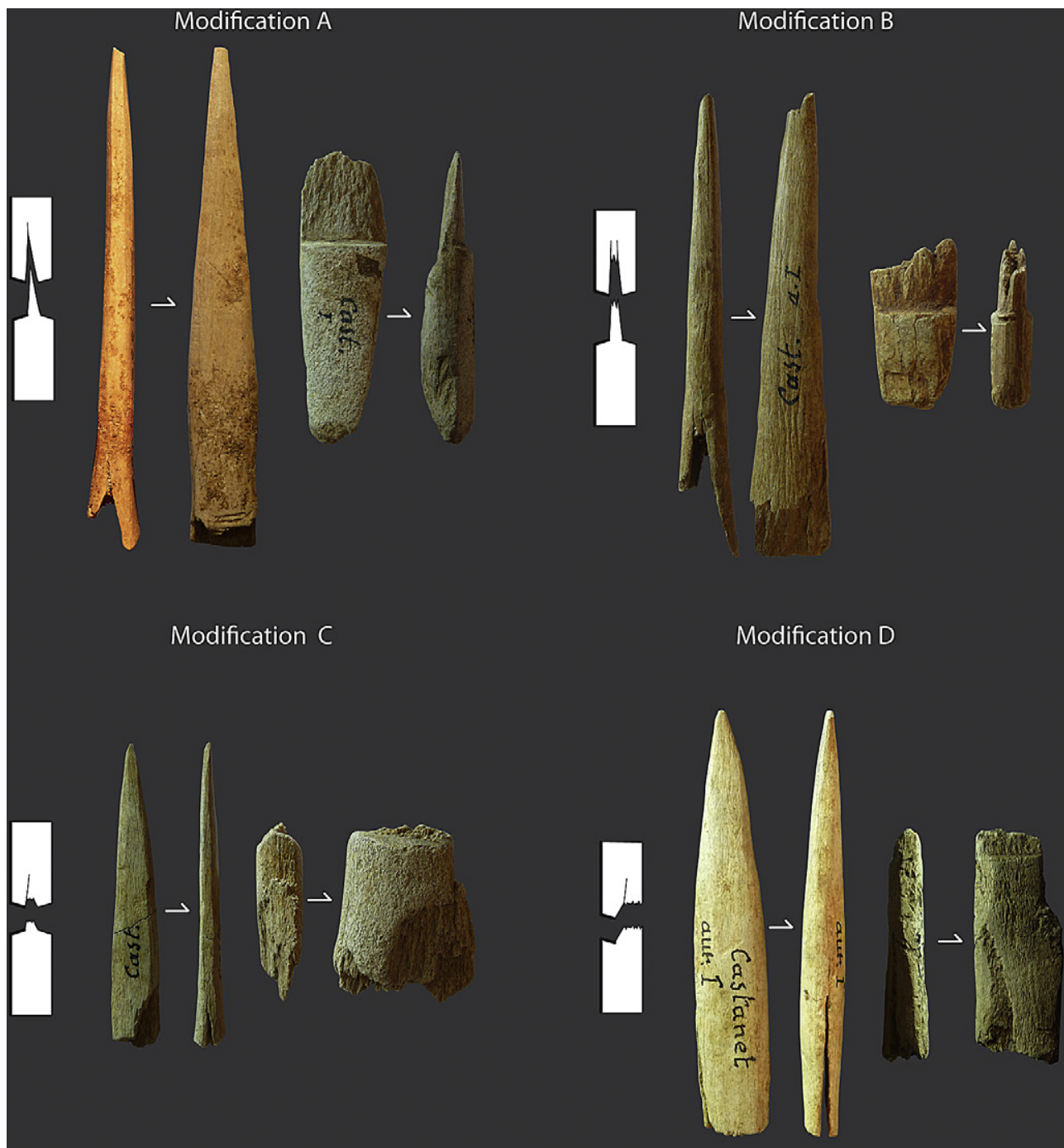

Modification E

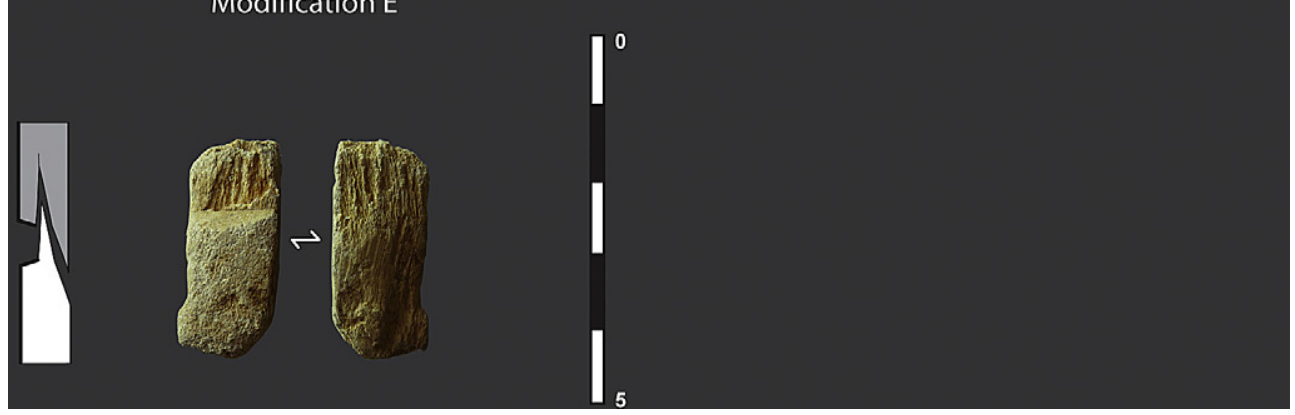

Fig. 17. Typology of incision and flexion modifications on archaeological SBP rough-outs and TP's. Except rought-out A (Blanchard), all pieces are from Castanet.

\section{Type C modification}

A roughed out SBP from Abri Castanet shows a split with no missing material and wings that retain residual incisions at their extremities. 16 waste products from Abri Castanet and 2 from Abri Blanchard showing bifacial incisions and no tongue could derive from this type of modification. However, it is possible that these waste products could be related to other technical operations such as blank reduction.

\section{Type D modification}

A roughed out SBP from Abri Castanet shows a split with no missing material, one incised wing and the other created by flexion. 3 waste products from Abri Castanet and 1 from Abri Blanchard with unifacial incision and saw-tooth fracture surface could be the result of this type of modification. As above, we cannot totally exclude the possibility that these derive from other kinds of technical operations. 
Type E modification

3 waste products from Abri Castanet serve as examples. They have a central tongue with traces of a unifacial incision on one face and a tearing surface on the other.

In addition, several pieces from our archaeological samples resemble the waste products of our failed attempts (Fig. 18). For instance, a pre-form from Castanet on which the proximal end shows a step fracture, as well as 6 rough-outs and 8 micro-flakes which are indistinguishable of our accidental breaks with a beveled fracture (Fig. 18.1-4). The 8 micro-flakes also resemble the wings of experimental rough-outs, torn away during attempted splitting (Fig. 18.5). Another archaeological example is close to an experimental product: a wing torn away during an attempt to lengthen the split (Figs. 18.6 and 15.2). It shows the same feathered end, curvature, and stigmata. Its fracture plane has a broad zone of compression with some grooves suggesting the insertion of a wedge (Fig. 18.6). Like the experimental piece, this zone is located a

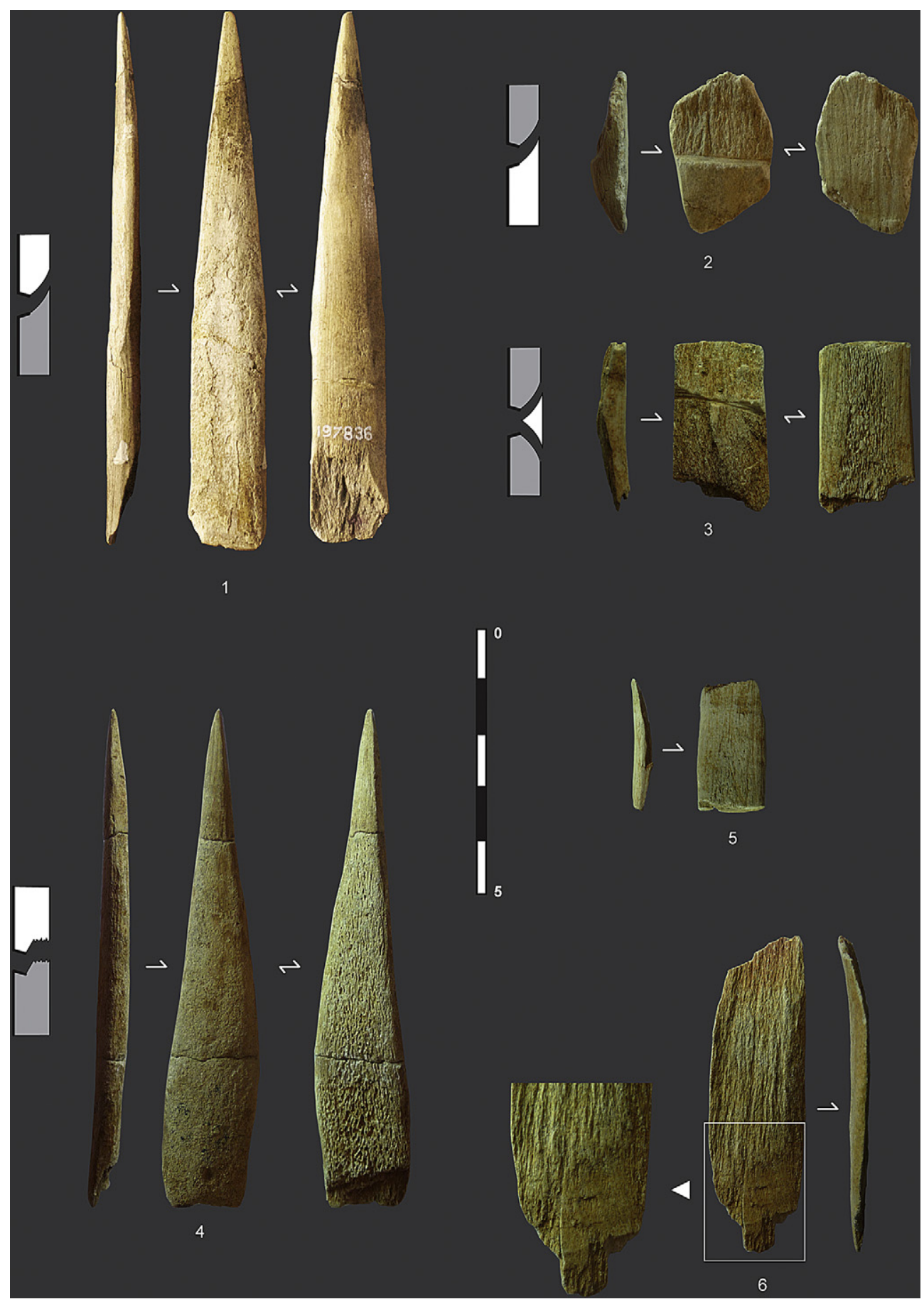

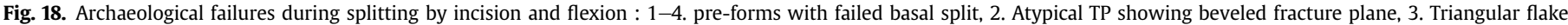

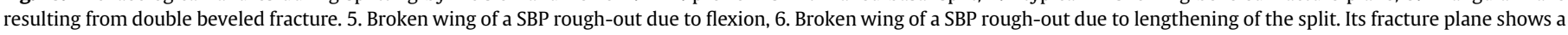
zone of compression suggesting the insertion of a wedge. Except $\mathrm{n}^{\circ} 1$ (Blanchard), all pieces are from Castanet. 
few millimeters back from the extremity suggesting that the split was not produced by cleavage but in fact preceded it. The high degree of working evident on the flake implies that the split was created on a rough-out that had already been at least partially shaped. Finally, several TP from Abri Castanet $(n=8)$ preserved traces of failed attempts at splitting on their proximal ends.

\section{Implications of our experiments for the interpretation of the design of SBP's from abris Castanet and Blanchard}

\subsection{The basal modification of SBP's: a complex procedure involving incision, flexion and cleavage}

Our analysis of the archaeological material from Abris Blanchard and Castanet supports the Peyrony hypothesis according to which basal splits involved a process of incision and flexion. However, Peyrony's scenario only accounts for the initiation of the split and ignores the need to lengthen the latter by cleavage, a technique first proposed by Henri-Martin and then by Knecht. Our experimental reconstructions have shown that this final cleavage, for which evidence has been found on an isolated wing (cf. Fig. 18.6), is obligatory for obtaining SBP's comparable to archaeological ones; in other words, with a sufficiently long and narrow split and no material missing between the wings. In sum, our archaeological SBP's with intact bases have wings that systematically fit back together, as is the case for previously studied assemblages of SBP's (HenriMartin, 1931; Leroy-Prost, 1975, 1979; Knecht, 1991, 1993; Liolios, 1999, 2006; Pétillon, in press).

To summarize, the modification procedure applied to SBP's from Abris Castanet and Blanchard, which we abbreviate as IFC (for incision, flexion and cleavage) can be described as a mixed process that combines the techniques proposed by Peyrony and HenriMartin. Indeed these procedures are fully complementary. The creation of an incision followed by flexion is preparatory to cleavage. The toughness of the material makes cleavage directly on the bases difficult. This difficulty is overcome by cutting an incision, then flexing to start the split, exploiting the fibrous structure of the antler. Subsequent cleavage allows for the lengthening of the split and, after re-shaping the contours of the base, to produce SBP's with narrow splits and no material missing between the wings.

\subsection{Additional data on the design of SBP's}

As we indicated above, the SBP's from Abris Castanet and Blanchard are, in the main, extracted from medium and large diameter beams of reindeer antler, probably shed antlers, at least at Abri Castanet. The thickness of the compact tissue on such antlers is between 5 and $11 \mathrm{~mm}$. Nevertheless, the SBP's in our sample have an average thickness of $6 \mathrm{~mm}$ (Blanchard: $n=13$, mean of $6.46 \mathrm{~mm}$; Castanet: $n=51$, mean of $6 \mathrm{~mm}$ ), and never exceed $9 \mathrm{~mm}$. The absence of very thick SBP's results from the procedures employed to modify the bases. We have been able to show experimentally that blanks derived from shed antler for which the thickness of compact tissue is greater than $8 \mathrm{~mm}$ are highly rigid and difficult to flex, even after prolonged soaking. The Aurignacians apparently avoided this problem by not exploiting large caliber antlers or by scraping them to reduce the compact tissue thickness on such antlers. Even so, a certain number of mishaps could not be avoided as attested by several blanks and production debris on which the fractures resemble those obtained experimentally on blanks that were too thick or insufficiently soaked in advance.

As Vezian and Vezian suggested for the SBP's from Tuto de Camalhot (Vezian and Vezian, 1970), at least some of the points from Abris Castanet and Blanchard were undoubtedly produced in series. Vezian and Vezian based their argument on a piece with a split base and a tongue at the opposite (distal) end. Two pieces of this type are found at Abri Castanet (Fig. 4). Two others were found at Abri Blanchard (Didon, 1911a, Fig. 4, p. 326), but are not part of the collections that we have so far studied. Hahn (1988, p. 14) hypothesized that these pieces were related to reconfiguration of the proximal end of SBP's. This interpretation seems unlikely given that the split bases on these pieces show no fractures. For Vezian and Vezian, these are rough-outs derived from a long blank which would have been separated into segments at intervals by incision and flexion. On the two pieces from Castanet, as well as those from Blanchard illustrated by Didon, the wings are entirely shaped into final form. This leads us to suppose that each time a split was initiated at the base of a blank, that extremity was entirely finished before proceeding to the next incise-and-flex event higher up the blank. This argument explains the significant length of certain blanks, such as that from Castanet illustrated in Fig. 16. It is reasonable to ask whether this very long $(233 \mathrm{~mm})$ and very narrow (13 mm) blank was destined to produce several SBP's. In like fashion, several TP's from 90 to $160 \mathrm{~mm}$ long and with a regular body, appear unexhausted and would have allowed the fabrication of additional points.

As concerns the finishing of the SBP's, abrasion was not at all used at Castanet and Blanchard, even though we had found it particularly effective for the final shaping of the split bases, for example. Scraping was the only finishing technique identified by us in our archaeological sample.

\section{Conclusion}

Uncertainty has long surrounded the question of the fabrication of Aurignacian SBP's, and especially the creation of their basal splits. This question had already pitted Peyrony against HenriMartin at the beginning of the last century: the former defending the hypothesis that the split bases were obtained by the extraction of a volume of material (TP) by techniques of incision and flexion; the latter proposed direct cleavage of the bases. We had to wait until Knecht's 1990's analysis of ca. 30 assemblages of points in order to end debate by providing evidence in support of HenriMartin's hypothesis. In the context of her analysis, Knecht hypothesized that the famous TP's, brought to light by Peyrony, served in reality to produce shims which functioned in the hafting of SBP's onto wooden spear shafts. Our study of the osseous material from Abris Castanet and Blanchard, as well as our experimental reconstructions, contradict Knecht's conclusions.

At Castanet and Blanchard the split-base was obtained by a procedure that we have named procedure IFC, based on the combined and complementary use of incision and flexion already seen by Peyrony, and of cleavage, proposed by Henri-Martin. Given the physical and mechanical properties of antler which constrain direct cleavage of the point bases, incision and flexion permit the initiation of the split taking advantage of the fibrous structure of the antler. This first operational step requires a system of chocks to exploit pre-forms softened by prolonged water-soaking. Once initiated, the split can be easily lengthened by cleavage. As Peyrony understood, the TP's are indeed the waste products of the splits produced after incision and flexion. Our experimental reproductions lead us to reject definitively Knecht's hypothesis of shim "cores". The shims identified by Knecht in the osseous assemblage from Abri Castanet are not a real technical category as they include broken SBP wings and accidental debris. A significant contribution of our research is the demonstration that the presence of TP's in an Aurignacian assemblage is uncontestable proof of onsite fabrication of PBF's.

The use of procedure IFC at Castanet and Blanchard is not an isolated case. It can be deduced from the presence of TP's, but also 


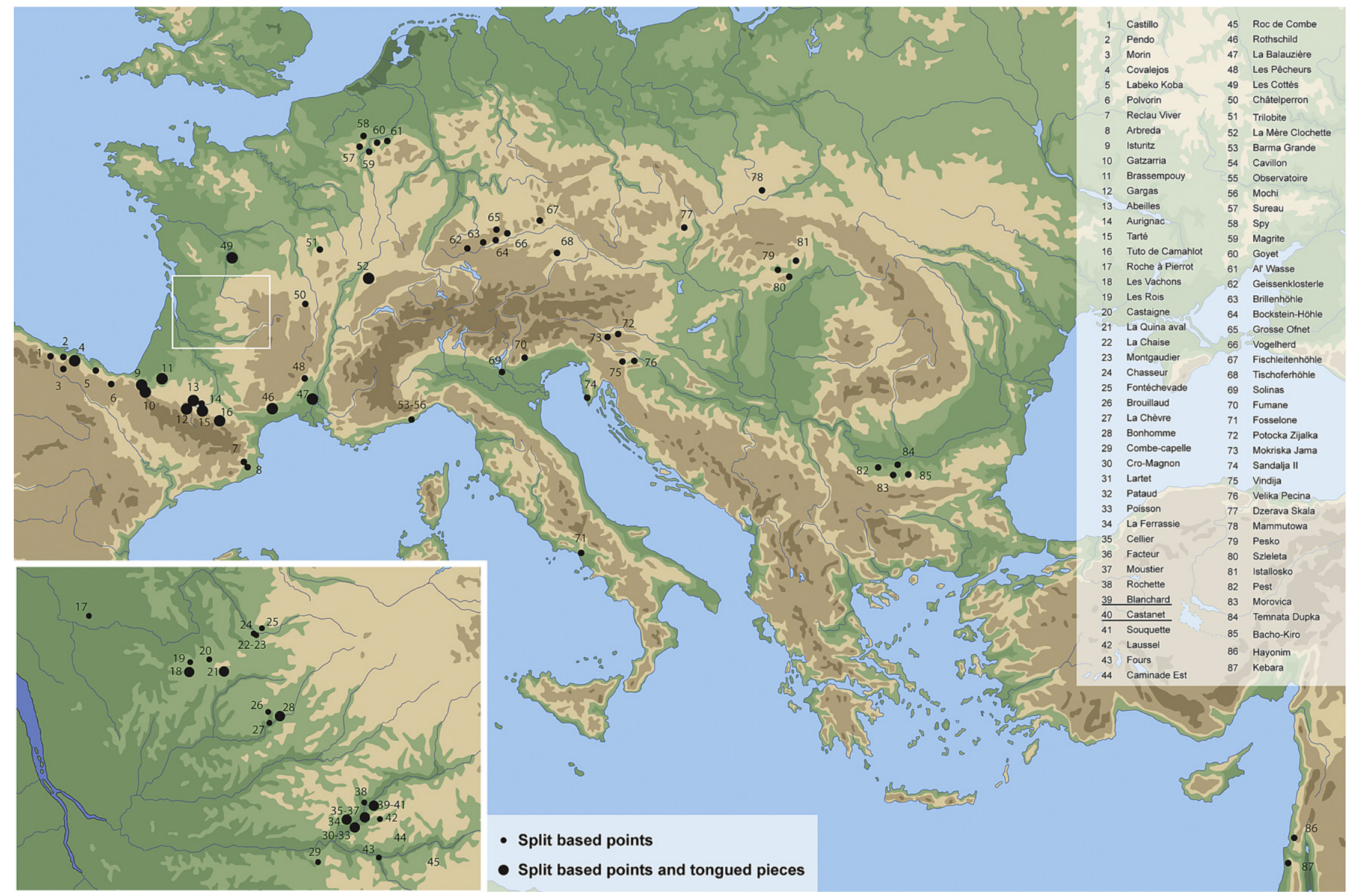

Fig. 19. Distribution map of known SBP's and TP's 
from the existence of rare SBP rough-outs resulting from incision and flexion as at Abri Pataud (cf. 4.3.2.4., Vercoutère, 2004; Chiotti et al., 2003: 188) and at the grotte des Hyènes at Brassempouy ( $c f$. 4.3.2.1., Pétillon, in press). In addition, there are two pieces from the Charente noted by Leroy-Prost as having an "imperfect" split: one from Vachons with material missing from between the wings, and the other from La Quina, with a part of the tongue preserved (Leroy-Prost, 1975: 111). The piece from La Quina flies in the face of Henri-Martin's statement that this site saw only SBP's modified by simple basal cleavage. According to our bibliographic research and personal observations, the IFC procedure exists at 23 sites (Castanet and Blanchard included, Fig. 19). This number must however be viewed as a minimum because of the large number of pre-modern excavations which saw a highly selective and incomplete recovery of relevant objects, and the cursory descriptions of osseous industries in the resulting publications. Typical TP's, such as those recognized at Castanet and Blanchard (which constitute half of all known TP's), are rarely noted. The IFC procedure is therefore more than just frequent: it is known from Cantabria through the principal regions of Aurignacian occupation in France (Fig. 19). On a larger scale, it is found everywhere in Europe where there are important concentrations of Aurignacian sites.

The detailed study of the osseous industry from other sites should allow a definition of the geographic distribution of this procedure. However, it seems very improbable that another technical solution to split-base production could have existed. In essence, our experimental replications have shown that the physical properties and mechanics of antler made direct cleavage of the blanks very difficult. In order to successfully cleave this material, it is prerequisite to initiate the split. We have been able to succeed by exploiting the fibrous properties of antler using the techniques of incision and flexion and we doubt whether other approaches are possible. In spite of a wide geographic distribution, the different assemblages of SBP's could be based on a single operational sequence. Nonetheless, variability among different assemblages manifests itself in different volumetric designs of points (Liolios, 2006) as well as in their size (Leroy-Prost, 1975; Cattelain, 2010; Pétillon, in press), which can also vary significantly within a single assemblage, as is the case at Abri Castanet. Such morphometric variation in points may suggest functional differences (mode of throwing, type of game), a question that will be addressed through experimental propulsion. Before that however, we need to resolve issues surrounding the hafting of the points, the next question to be addressed in our experimental program. Even if the present study allows us to reject Knecht's hypothesis of the purposeful production of reindeer antler shims, it does not necessarily falsify the hafting system that she proposed (use of shims made of perishable materials: Knecht, 1993; Liolios, 1999). New experiments, coupled with preserved usetraces on the proximal ends of points ought to throw light on this question.

Notes:

(1) Organized within the context of the Franco-Americain collaborative exchange entitled "Aurignacian Genius: Art, daily life and social identity of the first modern humans of Europe", UMI 3199CNRS-NYU \& UMR 5608-TRACES, U. of Toulouse 2-Mirail, funded by a three-year grant from the Partner University Fund and the Andrew Mellon Foundation.

(2) In agreement with one anonymous reviewer's terminological concerns, we have chosen to replace the act of "sawing" with that of "incision", by which we mean the use of an unretouched edge to cut into a material, leaving behind a deep, linear impression that we refer to as an "incision." The best analogue for our application of the term is the use of a scalpel by a surgeon, the result of which is an incision.

(3) By 1928, Peyrony had already excavated several sites yielding what we now know as Early Aurignacian (then called Middle Aurignacian according to Breuil's 1912 scheme): Pagès (since 1908), La Souquette (1909), Castanet (1911-1912 and 19241925), Roc de Combe-Capelle (since 1912), Abri Lartet (since 1917), La Ferrassie (1909-1924), etc. (dates from Groenen, 1994).

(4) Heretofore, we use the term shim as a gloss for the French clavette. Shims are used in carpentry, masonry and other industrial domains to separate and adjust the spacing between items. The term "shim" seems to us preferable to the term "wedge" employed by Knecht (Knecht, 1993), which is also widely employed to designate beveled tools used in indirect percussion for a diverse range of splitting tasks.

(5) Incremental analysis of mammalian teeth currently being undertaken by W. Rendu (UMR 5608-TRACES) should clarify issues of seasonality of predation at Abri Castanet.

\section{Acknowledgments}

The excavations undertaken at Abri Castanet and Blanchard have been supported since 1994 by generous grants from the United States National Science Foundation, the Direction régional des affaires culturelles d'Aquitaine (DRAC-Aquitaine), the L.S.B. Leakey Foundation, the Reed Foundation, the Rock Foundation, the Fine Foundation, UMI 3199-CNRS-NYU (Center for International Research in the Humanities and Social Sciences), the Institute for Ice Age Studies, the Theodore Dubin Foundation, the Service archéologique départemental (SAD) de la Dordogne.

We thank the curators and museum staff who welcomed us and facilitated access to collections: Jean-Jacques Cleyet-Merle, André Morala, Peggy Jacquement and Nicolas Bernard of the Musée National de Préhistoire des Eyzies; William A. Parkinson, Jamie Kelly and Ryan Gross of the Field Museum (Chicago) and Paul Beelitz of the American Museum of Natural History (New York).

Experiments were organized within the context of the FrancoAmerican collaborative exchange entitled "Aurignacian Genius: Art, daily life and social identity of the first modern humans of Europe", UMI 3199-CNRS-NYU \& UMR 5608-TRACES, U. of Toulouse 2-Mirail, funded by a three-year grant from the Partner University Fund and the Andrew Mellon Foundation.

We thank our colleagues and friends who participated in the experimental program from the discussion of the protocol, through the access and shipping of raw material, to the involvement on experiments: Lise Aurière, Raphaelle Bourrillon, Claire Heckel, Florent Le Mené, Romain Mensan, Joelle Nivens, John O'Hara, Mathieu Lejay. We especially thank Ned Gaines who was instrumental in obtaining the Alaskan caribou antler used in the experiments.

We are also grateful to the members of the French research program "Animal resources" (dir. M. Christensen and G. Goutas, UMR 7041) for their useful comments and to the anonymous reviewers that helped us to improve the original manuscript.

\section{References}

Bachellerie, F., Bon, F., Deschamps, M., Eizenberg, L., Henry-Gambier, D., Mourre, V., Normand, C., Pelegrin, J., Primault, J., Scandiuzzi, R., Thiebaut, Céline, 2011. La signature archéologique de l'activité de chasse appliquée à la comparaison des industries moustériennes, châtelperroniennes, et aurignaciennes des Pyrénées: nature des équipements et fonctions des sites. In: Haltes De Chasse En Préhistoire. Quelles Réalités Archéologiques?, Actes Du Colloque International du 13 Au 15 Mai 2006, Université Toulouse II-Le Mirail. Palethnologie 3, Toulouse, pp. $131-168$.

Bazile, F., Sicard, S., 1999. Le premier Aurignacien du Languedoc Oriental dans son contexte méditerranéen. In: Sacchi, D. (Ed.), Les faciÀs leptolithiques du 
nord-ouest méditerranéen: milieux naturels et culturels. Soci»t» Pr»historique Franiaise, Paris, pp. 117-125.

Billamboz, A., 1977. L'industrie du bois de cerf en Franche-Comté au Néolithique et au début de l'Age du Bronze. Gallia préhistoire 20, 91-176.

Boeda, E., Geneste, J.M., Griggo, C., 1999. A Levallois point embedded in the vertebra of (Equus africanus): hafting, projectiles and Mousterian hunting weapons. Antiquity $73,394-402$.

Bon, F., 2002. L'Aurignacien entre Mer et Océan. Réflexion sur l'unité des phases anciennes de l'Aurignacien dans le sud de la France. In: XXIX Mémoire de la Société Préhistorique Française. Société Préhistorique Française.

Bon, F., 2005. Little Big Tool. Enquête autour du succès de la lamelle. In: LebrunRicalens, F. (Ed.), Productions Lamellaires Attribuées à l'Aurignacien: Chaînes Opératoires Et Perspectives Technoculturelles, Archéologiques, pp. 429-484. Presented at the XIVe Congrès de l'UISPP, Musée National d'Histoire et d'Art du Luxembourg, Liège.

Bon, F., 2009. Préhistoire: La fabrique de l'homme. Seuil.

Bon, F., Bodu, P., 2002. Analyse technologique du débitage aurignacien. In: Schider, B. (Ed.), L'Aurignacien de la grotte du Renne. Les fouilles d'André LeroiGourhan á Arcy-sur-Cure (Yonne). XXXIV supplément de Gallia Préhistoire, CNRS éditions, pp. 115-133.

Bon, F., Teyssandier, N., Bordes, J.-G., 2010. La signification culturelle des équipements lithiques. In: Otte, M. (Ed.), Les Aurignaciens, Civilisations Et Cultures, pp. 49-72. Paris.

Bordes, J.G., 2002. Les interstratifications Châtelperronien/Aurignacien du Roc-deCombe et du Piage (Lot, France). Analyse taphonomique des industries lithiques implications archéologiques. Ph.D diss., Université Bordeaux 1, France.

Bordes, J.-G., Lebrun-Ricalens, F., Castel, J.-C., Ducasse, S., Faivre, J.-P., Feruglio, V. Henry-Gambier, D., Lacrampe-Cuyaubère, F., Laroulandie, V., Lenoble, A., Martin, H., Maureille, B., Morala, A., Renard, C., Rendu, W., Rigaud, S., Rougier, H. Tartar, E., Texier, J.-P., Teyssandier, N., 2008. Les débuts du Paléolithique supérieur dans le Sud-Ouest de la France: fouilles 2004-2006 au Piage (Fajoles, Lot). Problématique et premiers résultats. In: Jaubert, J., Bordes, J.-G., Ortega, I. (Eds.), Les Sociétés Du Paléolithique Dans Un Grand Sud-Ouest De La France: Nouveaux Gisements, Nouveaux Résultats, Nouvelles Méthodes, Journées SPF, Université Bordeaux 1, Talence, 24-25 Novembre 2006, pp. 261-288.

Bricker, H.M., 1995. Le paléolithique supérieur de l'abri Pataud, Dordogne, Documents d'Archéologie Française (DAF). Éd. de la Maison des sciences de l'homme, Paris.

Broglio, A., Angelucci, D.E., Peresani, M., Lemorini, C., Rossetti, P., 1996. L'industrie protoaurignacienne de la Grotta di Fumane: données preliminaires. In: Proceedings of the XIII UISPP Congress, (Section 6-The Upper Palaeolithic, Subsection "The Industries in Their Paleoecological and Chronostratigraphic Context"), pp. 495-502.

Callow, P., 1986. The flint tools. In: Callow, P., Cornford, J. (Eds.), La Cotte De St. Brelade. Norwich, UK, pp. 251-314.

Cattelain, P., 2010. Les armes. In: Otte, M. (Ed.), Les Aurignaciens, Civilisations Et Cultures, pp. 113-135. Paris.

Chiotti, L., Patou-Mathis, M., Vercoutère, C., 2003. Comportements techniques et de subsistance à l'Aurignacien ancien: la couche 11 de l'abri Pataud (Dordogne). Gallia Préhistoire 45, 157-203.

Delage, F., 1938. L'Abri de la Souquette à Sergeac, Dordogne. Bulletin de la Société historique et archéologique du Périgord LXV, 104-126.

Delluc, G., Delluc, B., 1978. Les manifestations graphiques aurignaciennes sur support rocheux des environs des Eyzies (Dordogne). Gallia préhistoire 21, 213-332.

Didon, L., 1911a. L'Abri Blanchard des Roches. Bulletin de la Société historique et archéologique du Périgord 87 (246-241), 321-345.

Didon, L., 1911b. Faits nouveaux constatés dans une station aurignacienne, l'abri Blanchard des Roches (près Sergeac). L'Anthropologie 23, 603.

Feustel, R., 1973. Technik der Steinzeit: Archäolithikum-Mesolithikum. des Museums für Ur- und Frühgeschichte Thüringens. H. Böhlaus Nachfolger, Weimar.

Groenen, M., 1994. Pour une histoire de la préhistoire: le Paléolithique. Editions Jérôme Millon.

Hahn, J., 1988. Fiche sagaie à base fendue. In: Camps-Fabrer, H. (Ed.), Fiches typologiques de l'industrie osseuse préhistorique. Cahier I: sagaies. de l'Université de Provence, Aix-en-Provence.

Hays, M., Lucas, G., 2001. Experimental investigations of aurignacian dufour bladelets. In: Hays, M.A., Thacker, P.T. (Eds.), Questioning the Answers: Re-solving Fundamental Problems of the Early Upper Paleolithic. British Archaeological Reports International Series. Archaeopress, Oxford, pp. 109-116.

Henri-Martin, L., 1931. La station Aurignacienne de La Quina. Impr. Ouvrière, Angoulême, France.

Henri-Martin, G., 1963. Coexistence des pointes à base fendue et non fendue dans l'aurignacien de La Quina. Archeoloski Vestnik XIII-XIV, 107-110.

Kervinio, P., Mensan, R., Gardère, P., 2006. La coupe Peyrony (Rapport de Fouille programmée de l'abri Castanet, année 2006.).

Knecht, H., 1991. Technological Innovation and Design During the Early Upper Paleolithic (PhD, New York University).

Knecht, H., 1993. Splits and wedges: the techniques and technology of Early Aurignacian antler working. In: Knecht, H., Pike-Tay, A., White, R. (Eds.), Before Lascaux: the Complex Record of the Early Upper Paleolithic. CRC Press, Boca Raton, Etats-Unis, pp. 137-162.

Knecht, H., 1997. Projectile points of bone, antler, and stone. Experimental explorations of manufacture and use. In: Knecht, H. (Ed.), Projectile Technology, Interdisciplinary Contributions to Archaeology. Plenum Press, New York, pp. 192-212.
Kuhn, S.L., 2002. Pioneers of Microlithization: The "Proto-aurignacian" of Southern Europe. In: Archeological Papers of the American Anthropological Association 12. 83-93.

Laplace, G., 1966. Les Niveaux Castelperroniens, Protoaurignaciens et Aurignaciens de la Grotte Gatzarria á Suhare en Pays Basque (fouilles 1961-1963). Quartâr 17, 117-140.

Lartet, E., 1861. Nouvelles recherches sur la coexistence de l'homme et des grands mammifères fossiles réputés caractéristiques de la dernière époque géologique. Annales des Sciences naturelles II. Zoologie 15, 177-253.

Productions lamellaires attribuées à l'Aurignacien: Chaînes opératoires et perspectives technoculturelles. In: Lebrun-Ricalens, F. (Ed.), XIVe Congrès de l'UISPP, Liège 2-8 septembre 2001. Archéologiques I. Musée National d'Histoire et d'Art du Luxembourg.

Leroy-Prost, C., 1975. L'industrie osseuse aurignacienne. Essai régional de classification: Poitou, Charentes, Périgord. Gallia préhistoire 18, 65-156.

Leroy-Prost, C., 1979. L'industrie osseuse aurignacienne. Essai régional de classification: Poitou, Charente, Périgord (suite). Gallia préhistoire 22, 205-370.

Liolios, D., 1999. Variabilité et caractéristiques du travail des matières osseuses au début de l'Aurignacien: approche technologique et économique (PhD, Université Paris X-Nanterre).

Liolios, D., 2006. Reflections on the role of bone tools in the definition of the early aurignacian. Trabalhos de Arqueologia, 37-51.

McGregor, A., 1985. In: Bone, Antler, Ivory and Horn. The Technology of Skeletal Materials since the Roman Period. Barnes \& Noble, London \& Sydney.

Mensan, R., Bourrillon, R., Cretin, C., White, R., Gardere, P., Chiotti, L., Sisk, M.L. Clark, A.E., Higham, T., Tartar, E., 2012. Une nouvelle découverte d'art pariétal aurignacien à l'abri Castanet (France): contexte et datation. Paléo 23, 171-187.

Newcomer, M., 1977. Experiments in Upper Paleolithic bone work. In: Méthodologie Appliquée à L'industrie De L'os Préhistorique, Actes Du Colloque International Abbaye De Sénanque (Vaucluse), 9-12 Juin 1976. CNRS Editions, Paris, pp. 293302.

Normand, Ch., Beaune, S., Costamagno, S., Diot, M.-F., Henry-Gambier, D., Goutas, N., Laroulandie, V., Lenoble, A., O'Farrell, M., Rendu, W., Rios-Garaizar, J., Schwab, C. Tarino-Vinagre, A., Texier, J.-P., White, R., 2007. Nouvelles données sur la séquence aurignacienne de la grotte d'Isturitz (communes d'Isturitz et de SaintMartin-d'Arberoue, Pyrénées-Atlantiques). In: Evin, J. (Ed.), Congrès du centenaire, un siècle de construction du discours scientifique en Préhistoire, 3 , Paris, Sociéte préhistorique française, pp. 277-293.

Nuzhnyi, D., 1998. The preliminary results of experiments with aurignacian split based points production, hafting and usage. Préhistoire Européenne 13,117-132.

Oakley, K.P., Andrews, P., Keeley, L.H., Clark, J.D., 1977. A reappraisal of the Clacton spearpoint. Proceedings of the Prehistoric Society 43, 13-30.

Ortega Cobos, D., Soler, M., Maroto, J., 2005. La production de lamelles pendant l'Aurignacien archaïque dans la grotte de l'Arbreda (Espagne): organisation de la production, variabilité des méthodes et objectifs. In: Lebrun-Ricalens, F. (Ed.) Productions Lamellaires Attribuées à l'Aurignacien: Chaînes Opératoires Et Perspectives Technoculturelles, Archéologiques. Presented at the XIVe Congrès de l'UISPP, Musée National d'Histoire et d'Art du Luxembourg, Liège, pp. 359-374.

O'Farrell, M., 2005. Étude préliminaire des éléments d'armature lithique de l'Aurignacien ancien de Brassempouy. In: Lebrun-Ricalens, F. (Ed.), Productions Lamellaires Attribuées à l'Aurignacien: Chaînes Opératoires Et Perspectives Technoculturelles, Archéologiques. Presented at the XIVe Congrès de l'UISPP, Musée National d'Histoire et d'Art du Luxembourg, Liège, pp. 395-412.

Pelegrin, J., O’Farrell, M., 2005. Les lamelles retouchées ou utilisées de Castanet. In: Lebrun-Ricalens, F. (Ed.), Productions Lamellaires Attribuées à l'Aurignacien: Chaînes Opératoires Et Perspectives Technoculturelles, Archéologiques. Presented at the XIVe Congrès de l'UISPP, Musée National d'Histoire et d'Art du Luxembourg, Liège, pp. 103-121.

Pétillon, J.-M., L'industrie en bois de cervidé de l'Aurignacien ancien de la grotte des Hyènes. In: Henry-Gambier, D., Bon, F. (Eds.), L'Aurignacien De La Grotte Des Hyènes, Brassempouy (Landes), in press.

Peyrony, D., 1928. Pièces à languette de l'Aurignacien moyen. Anthropologie et Archéologie. Assoc. Française pour l'avancée des sciences, 439-441.

Peyrony, D., 1933. Les Industries «aurignaciennes» dans le bassin de la Vézère. Bulletin de la Société préhistorique française 30, 543-559.

Peyrony, D., 1935. Le gisement de Castanet, vallon de Castelmerle, commune de Sergeac (Dordogne). Bulletin de la Société préhistorique française 32, 418-443.

Peyrony, D., 1946. Le Gisement préhistorique de l'Abri Cellier au Ruth, commune de Tursac (Dordogne). Gallia 4, 294-301.

Plisson, H., Beyries, S., 1998. Pointes ou outils triangulaires? Données fonctionnelles dans le Moustérien levantin. Paléorient 24, 5-24.

Provenzano, N., 2001. Produits, techniques et productions à l'âge du bronze: l'industrie osseuse dans les Terramares de la moyenne vallée du Pô (PhD, Université Aix-Marseille II).

Shea, J.J., 1988. Spear points from the middle Paleolithic of the Levant. Journal of Field Archaeology 15, 441-450.

Shea, J.J., 2006. The origins of lithic projectile point technology: evidence from Africa, the Levant, and Europe. Journal of Archaeological Science 33, 823-846.

Shea, J., Davis, Z., Brown, K., 2001. Experimental tests of Middle Palaeolithic spear points using a calibrated crossbow. Journal of Archaeological Science 28, 807-816.

Sisk, M.L., Shea, J.J., 2009. Experimental use and quantitative performance analysis of triangular flakes (Levallois points) used as arrowheads. Journal of Archaeological Science 36, 2039-2047.

Smith, G., 2003. Damage inflicted on animal bone by wooden projectiles: experimental results and archaeological implications. Journal of Taphonomy 1, 3-13. 
Sonneville-Bordes, D. de, 1960. Le Paléolithique supérieur en Périgord. Delmas, Bordeaux, France.

Szmidt, C.C., Brou, L., Jaccottey, L., 2010. Direct radiocarbon (AMS) dating of splitbased points from the (Proto)Aurignacian of Trou de la Mère Clochette Northeastern France. Implications for the characterization of the Aurignacian and the timing of technical innovations in Europe. Journal of Archaeological Science 37, 3320-3337.

Tartar, E., 2012. The recognition of a new type of bone tools in Early Aurignacian assemblages: implications for understanding the appearance of osseous technology in Europe. Journal of Archaeological Science 39, 2348-2360.

Tartar, E., Teyssandier, N., Bon, F., Liolios, D., 2006. Equipement de chasse, équipement domestique: une distinction efficace? Réflexion sur la notion d'investissement technique dans les industries aurignaciennes. In: Astruc, L., Bon, $\mathrm{F}$ Léa, V., Milcent, P.-Y., Philibert, S. (Eds.), Normes techniques et pratiques sociales: de la simplicité des outillages pré- et protohistoriques, pp. 107-117. Antibes, France.

Tejero, J.-M., Christensen, M., Bodu, P., 2012. Red deer antler technology and early modern humans in Southeast Europe: an experimental study. Journal of Archaeological Science 39, 332-346.

Texier, P., 1994. Rapport géologique (Rapport de l'opération diagnostic de l'abri Castanet, année 1994.)

Teyssandier, N., 2007. l'émergence du Paléolithique supérieur en Europe: mutations culturelles et rythmes d'évolution. Paléo 19, 367-389.
Teyssandier, N., 2008. Revolution or evolution: the emergence of the Upper Paleolithic in Europe. World Archaeology 40, 493-519.

Teyssandier, N., Liolios, D., 2008. Le concept aurignacien: entre rupture préhistorique et obstacle épistémologique. Bulletin de la Société Préhistorique Française 105 (4), 737-747.

Thieme, H., 1997. Lower Palaeolithic hunting spears from Germany. Nature 385, $807-810$.

Vercoutère, C., 2004. Utilisation de l'animal comme ressource de matières premières non-alimentaires: industrie osseuse et parure, exemple de l'abri Pataud (Dordogne, France) (PhD, Université Paris I-Panthéon-Sorbonne).

Vezian, J., Vezian, J., 1970. Les gisements de la grotte de Saint-Jean-de-Verges (Ariège). Bulletin de la Société préhistorique de l'Ariège 25, 29-77.

Villa, P., Lenoir, M., 2006. Hunting weapons of the Middle Stone Age and the Middle Palaeolithic: spear points from Sibudu, Rose Cottage and Bouheben. Southern African Humanities 18, 89-122.

Villa, P., Boscato, P., Ranaldo, F., Ronchitelli, A., 2009. Stone tools for the hunt: points with impact scars from a Middle Paleolithic site in southern Italy. Journal of Archaeological Science 36, 850-859.

White, R., Mensan, R., Bourrillon, R., Cretin, C., Higham, T.F.G., Clark, A.E., Sisk, M.L., Tartar, E., Gardere, P., Goldberg, P., Pelegrin, J., Valladas, H., Tisnerat-Laborde, N. de Sanoit, J., Chambellan, D., Chiotti, L., 2012. Context and dating of Aurignacian vulvar representations from Abri Castanet, France. Proceedings of the National Academy of Sciences 109, 8450-8455. 